\title{
Furnishing an "Elastic Currency": The Founding of the Fed and the Liquidity of the U.S. Banking System
}

\author{
Mark Carlson and David C. Wheelock
}

\begin{abstract}
This article examines how the U.S. banking system responded to the founding of the Federal Reserve System (Fed) in 1914. The Fed was established to bring an end to the frequent crises that plagued the U.S. banking system, which reform proponents attributed to the nation's "inelastic" currency stock and dependence on interbank relationships to allocate liquidity and operate the payments system. Reform advocates noted that banking panics tended to occur at times of the year when the demands for currency and bank loans were normally at seasonal peaks and money markets were at their tightest. Moreover, they blamed the interbank system, upon which the banking system depended for seasonal accommodation and interregional payments, for transmitting shocks throughout the banking system. The article finds that after the Fed's founding, country national banks were much less dependent on correspondent banks for seasonal liquidity and that peaks in lending by individual Reserve Banks aligned with the liquidity needs of banks in their districts. Further, the article shows that after the Fed's founding, banks generally were less liquid and relied more heavily on deposits for funding, consistent with the idea that banks viewed the Fed as a reliable source of liquidity. The return of banking panics during the Great Depression, however, showed that the Fed was not, in fact, up to the challenge of serving as a full-fledged lender of last resort. (JEL E58, G21, N21, N22)
\end{abstract}

Federal Reserve Bank of St. Louis Review, First Quarter 2018, 100(1), pp. 17-44. https://doi.org/10.20955/r.2018.17-44

Mark Carlson is a senior economic project manager with the Board of Governors of the Federal Reserve System. David C. Wheelock is vice president and deputy director of research at the Federal Reserve Bank of St. Louis. Paul Morris provided research assistance. The authors thank Steve Williamson and Yi Wen for comments on a prior version of this article.

( ) 2018, Federal Reserve Bank of St. Louis. The views expressed in this article are those of the author(s) and do not necessarily reflect the views of the Federal Reserve System, the Board of Governors, or the regional Federal Reserve Banks. Articles may be reprinted, reproduced, published, distributed, displayed, and transmitted in their entirety if copyright notice, author name(s), and full citation are included. Abstracts, synopses, and other derivative works may be made only with prior written permission of the Federal Reserve Bank of St. Louis. 


\section{Carlson and Wheelock}

rules governing Federal Reserve (Fed) lending were enacted both during the Great Depression and following the crisis of 2007-08. In the 1930s, concerns that the Fed did too little to save the banking system or protect the economy prompted Congress to enact legislation that expanded the Fed's ability to lend to banks and other firms and restructured the Federal Reserve System in an effort to make it a more-responsive lender of last resort. In 2007-08, the Fed lent heavily to commercial banks and other financial institutions, in some cases using authorities granted during the Great Depression. Concerns that the Fed had too much latitude led Congress, in the Dodd-Frank Act, to rein in the Fed's ability to lend to distressed firms.

Economists and policymakers are interested in how banks respond to changes in regulation and the rules governing access to a lender of last resort to determine whether those changes have their intended effects. Such changes can affect banks' incentives to take risks, engage in certain activities, or grow in size, with implications for the broader economy. 2 New restrictions on a central bank's lending authority, for example, might cause banks to reduce the liquidity services they offer to their customers to lessen the chance they will need to borrow from the central bank, while an easing of restrictions might lead banks to take greater risks, knowing that the central bank will backstop them in a crisis.

This article examines how the U.S. banking system responded to the founding of the Federal Reserve System in 1914. The Federal Reserve was established primarily to bring an end to the recurring crises that plagued the U.S. banking system, which reform proponents saw as stemming from the nation's "inelastic" currency stock and dependence on interbank relationships to allocate liquidity and operate the payments system. The Federal Reserve Act was intended to solve these problems by creating a new currency-Federal Reserve notessupplied by regional Reserve Banks through lending to their member banks. Member banks would hold reserve deposits with their Reserve Bank and acquire additional reserves or currency from the Reserve Bank as needed to accommodate the short-term credit and liquidity needs of local commercial and agricultural activity. Moreover, the Reserve Banks would provide check clearing and other payments services to their members. Although not stated as such in the Federal Reserve Act, the Fed was intended to perform the functions of a central bank, including serving as lender of last resort for the banking system.

In focusing on the need for an elastic currency, reform advocates noted that banking crises tended to occur at times of the year when the demands for currency and bank loans were normally at seasonal peaks and money markets were at their tightest. Moreover, they blamed the interbank system, upon which the banking system depended for seasonal accommodation and interregional payments, for transmitting shocks throughout the banking system. Researchers have shown that market interest rates exhibited much less seasonal variability after 1914 than before, suggesting that the Fed's founders accomplished their goal of eliminating seasonal strains in money markets (e.g., Miron, 1986). $\underline{3}$ Others have shown that the balances that national banks held with correspondent banks in major cities were also less seasonally variable after the Fed's founding, suggesting reduced seasonal pressures on the interbank system (Carlson and Wheelock, 2016a,b). ${ }^{4}$ Further, Carlson and Wheelock (2016b) find that, as a percentage of their total assets, national banks held much lower levels of liquid assets, including cash and deposits with reserve agents (i.e., designated national banks during 1894-1914 and the Fed 
during 1921-28), after the Fed's founding, suggesting that the Fed's presence made banks comfortable operating with less liquidity.

This article builds on the prior studies by comparing the seasonal volatility and average levels of key bank balance sheet ratios before and after the Fed was established. Although we do not test formally whether the Fed caused or contributed to changes in bank balance sheets, the article presents new evidence that is consistent with the objective of the Fed's founders to relieve seasonal pressures on the banking system and prior research indicating that the presence of the Fed allowed banks to operate with lower liquidity buffers.

The article begins by describing the defects of the U.S. banking system that the Fed's founders hoped to rectify. We then compare the seasonal variation in national bank balance sheets between the 20 years before the Fed's founding and the 1920s. Further, we show that differences in the seasonal patterns of lending by the individual Reserve Banks were consistent with regional differences in the timing of seasonal liquidity demands, especially between predominantly agricultural regions and regions with more-diversified economies. Finally, we compare the levels of key balance sheet ratios before and after the founding of the Fed to provide further evidence on how the presence of the Fed might have affected banks' willingness to assume greater liquidity risk or leverage.

\section{HISTORICAL BACKGROUND}

The Federal Reserve System was established in 1914 to correct defects of the American banking system that reformers blamed for the banking panics that occurred every few years throughout the nineteenth and early-twentieth centuries. Panics were marked by widespread suspensions of cash withdrawals and payments, sharp increases in interest rates, and bank failures. They were widely attributed to the nation's inelastic currency, the concentration of the banking system's reserves in a small number of banks in New York City and a few other large cities, and the dependence of the system on interbank relationships to move funds between regions (see, e.g., Kemmerer, 1910, and Sprague, 1910).

Reform proponents, naturally, called for the creation of an "elastic currency," by which they meant a money stock whose supply adjusts to fluctuations in demand. At the time, the U.S. currency stock consisted primarily of national bank notes (notes issued by commercial banks with federal charters in proportion to the amount of U.S. government bonds they held in their portfolios), notes issued by the federal government during the Civil War ("greenbacks"), and various gold and other coins issued by the U.S. Treasury. Whereas the stock of currency (and coin) was relatively inflexible in the short run, the demands for money and credit, and the volume of payments, were highly variable. Reflecting the importance of agriculture in many parts of the country, money and credit demands fluctuated widely during the year, resulting in substantial intra-year variability in interest rates and money market conditions. Contemporary observers noted that banking panics tended to occur at the times of the year when the seasonal strains on money markets were most acute (see, e.g., Kemmerer, 1910, and Sprague, 1910). $\underline{5}$ 


\section{Carlson and Wheelock}

Figure 1

\section{Structure of the National Banking System}

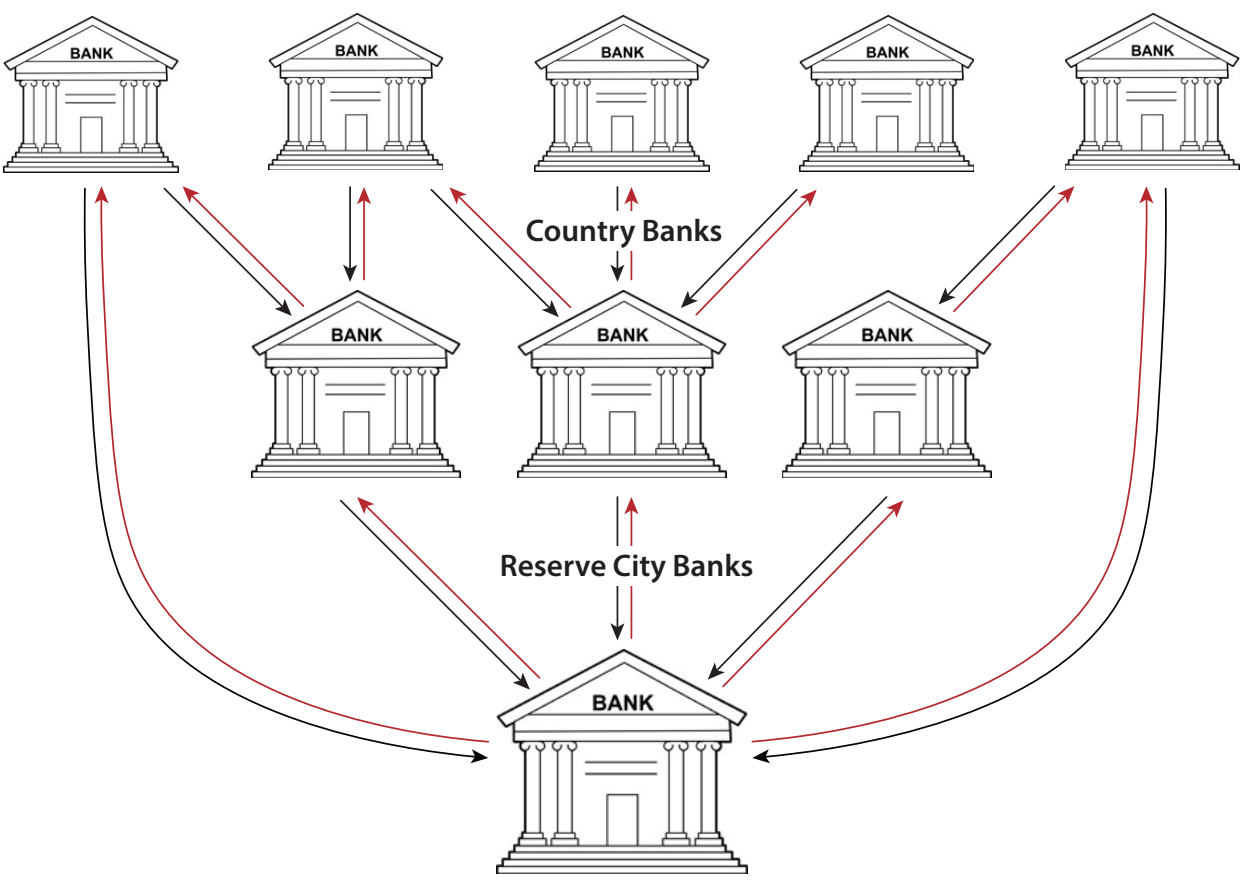

Central Reserve City Banks

NOTE: Arrows represent flows of funds between national banks in different tiers of cities. Typically, country banks maintained deposits with banks in reserve cities and central reserve cities, and reserve city banks maintained deposits with banks in central reserve cities. (Some banks also held deposits with banks in their own or a lower-tier city.) A deposit that one bank maintains in another bank (known as the correspondent) is an asset of the depositing bank and referred to as a deposit "due from" the correspondent bank. That deposit is a liability of the correspondent bank and is thus a deposit "due to" the first bank. Flows of funds between banks included withdrawals or additions to deposits with correspondents, interbank borrowing, and other payments. Banking panics were often characterized by suspensions of payments that interrupted interbank flows and cascaded through the different tiers of the system.

Observers also noted that the U.S. banking system was highly dependent on interbank connections. Unlike the banking systems of most countries, which were dominated by a few banks with nationwide branches, the U.S. banking system was composed of thousands of single-office "unit" banks that depended on correspondent relationships with banks in other cities and towns for payments and other services. Banks throughout the country maintained relationships with correspondent banks in larger cities to facilitate payments, invest surplus funds, and obtain additional funds needed to satisfy local demands for money or loans. The structure of reserve requirements imposed under the National Banking Acts of the 1860s further encouraged growth of the interbank system. Banks with federal charters, that is, national banks, were grouped into three reserve tiers. Those located in designated central reserve cities (originally just New York City, but later also Chicago and St. Louis) were required to maintain cash reserves equal to at least 25 percent of their deposit liabilities. National banks in desig- 
nated reserve cities were also subject to a 25 percent requirement, but those banks could maintain as much as half of their required reserves in the form of deposits at national banks in central reserve cities. National banks in all other cities and towns, known as country banks, were subject to a 15 percent reserve requirement, three-fifths of which could be held as deposits at reserve city or central reserve city banks. $\frac{6}{}$ Most banks held a large portion of their reserves in the form of correspondent balances, which typically paid interest, rather than as vault cash. Indeed, many banks maintained correspondent balances well in excess of their statutory reserve requirement because of their usefulness for making payments and buffering seasonal liquidity demands. Banks would draw down their interbank deposits or borrow from their correspondents when local demands for cash and loans were high and deposit surplus funds with their correspondents when local demands were low. Figure 1 illustrates the structure of the national banking system.

Contemporaries viewed the interbank system as something of a necessary evil. Banks depended on the system to meet local demands for liquidity and for making interregional payments. However, the system seemed unable to supply enough funds to meet local needs (at least according to borrowers who complained about seasonal spikes in interest rates), and the system was vulnerable to disruptions caused by panics, especially in the central money markets. Major banking panics occurred in 1893 and 1907, for example, when banks throughout the country were unable to obtain funds from their New York City correspondents after those banks suspended withdrawals (Sprague, 1910). Calomiris and Carlson (2017) show that banks with substantial correspondent business were especially vulnerable to suspensions by New York City banks because of their inability to withdraw funds from New York City banks to satisfy the demands of their own respondents. Although the banks of New York City and other cities worked together under the auspices of their local clearinghouses to protect themselves and limit the fallout of panics, the system lacked a lender of last resort that could rapidly inject cash or other forms of liquidity into the banking system to halt a panic.

\section{THE FED'S IMPACT}

The Fed's founders believed that banking panics could be eliminated by solving the "inelastic currency" problem, which was reflected most obviously in wide seasonal fluctuations in interest rates and money market conditions. Interest rates displayed much less seasonal variability after the Fed's founding (Friedman and Schwartz, 1963, and Miron 1986), and the Fed's discount window lending added liquidity to the banking system at the times of the year when previously money markets had tightened and interest rates spiked (Carlson and Wheelock, 2016b). Further, both the average volume and seasonal variability of interbank deposits were much reduced after the Fed was established (Carlson and Wheelock, 2016b).

Following Carlson and Wheelock (2016a,b), we infer the importance of seasonal forces on national bank balance sheets from principal components analysis of intra-year changes in various balance sheet items across U.S. states. The principal components help reveal the main drivers of changes in item values over time. For example, if the first principal component exhibits a markedly seasonal pattern and explains a high percentage of the underlying cova- 


\section{Carlson and Wheelock}

riance of the data, we conclude that seasonal forces were an important influence on the given balance sheet item. Principal components analysis is also useful for detecting changes in the importance of seasonal forces on the item over time. Further, the analysis allows us to identify the states whose banks contribute the most to the components and, thus, whose balance sheets exhibit the greatest seasonal variability.

Our data consist of state-level balance sheet information for country national banks over the 20 years prior to the Fed's establishment, 1894-1914, and for 1921-28. We omit the years 1915-20 to avoid the three-year phase-in period for the Fed's member banks to adjust to reserve requirements specified in the Federal Reserve Act and the impact of World War I financing on Federal Reserve and member bank balance sheets. ${ }^{7}$ The frequency of observations varies by year, reflecting the calls issued by the Comptroller of the Currency for banks to report their balance sheets. The Comptroller issued five calls per year during 1894-1914 and from three to five per year during 1921-28.

Figure 2 plots the first principal component of changes between reporting dates in net balances due from national banks for country banks, scaled by their initial-period total assets; that is, $\left(\right.$ Net Due From $_{t}-$ Net Due From $\left.{ }_{t-1}\right) /$ Assets $_{t-1} \cdot \frac{8}{}$ The first principal component explains 26 percent of the variation in the data and exhibits a decidedly seasonal pattern. The pattern appears less seasonal in the 1920s, with less intra-year variability, consistent with reduced seasonal pressure on the interbank system after the Fed was established. 9

Besides drawing on their accounts with correspondent banks, country banks often borrowed from their correspondents for short periods, especially at times of the year when local demands for cash and loans were highest. Figure 3 displays the first principal component of changes in the short-term borrowing of country banks scaled by their total assets. $\underline{10}$ The first principal component explains 44 percent of the variation in the data and exhibits a decidedly seasonal pattern. The intra-year variation appears somewhat lower in the 1920s, but not markedly so. Although the balance sheet information for national banks does not indicate the source of their loans, in the 1920s national banks likely borrowed mainly from the Fed rather than from other national banks. We show that the seasonal pattern of Federal Reserve lending in the 1920s was similar to the seasonal pattern of borrowing by national banks.

Further evidence of reduced seasonal pressures on country bank balance sheets is provided in Figure 4, which plots the first principal component of changes in the reserves-to-assets (hereafter reserves/assets) ratio. (We define reserves as the sum of vault cash, cash items in the process of collection, and deposits with reserve agents.) The principal component accounts for 26 percent of the variance in the data and exhibits a highly seasonal pattern. Country banks, especially in farming regions, faced wide seasonal fluctuations in their customers' demands for cash and loans. In peak seasons, country banks experienced both high loan demand and cash withdrawals. To meet those demands, country banks drew down their reserves of cash and correspondent deposits, causing their reserves/assets ratios to fall. When country banks experienced slack demand for loans and cash, they built up their reserves, causing their reserves/assets ratios to rise. As Figure 4 shows, the intra-year variability in the first principal component of changes in the reserves/assets ratio was much lower in the 1920s, suggesting that Federal Reserve lending enabled banks to smooth their reserves/assets ratios across seasons, which made them less vulnerable to shocks. 


\section{Figure 2}

\section{Interbank Deposit Flows, 1894-1914 and 1921-28}

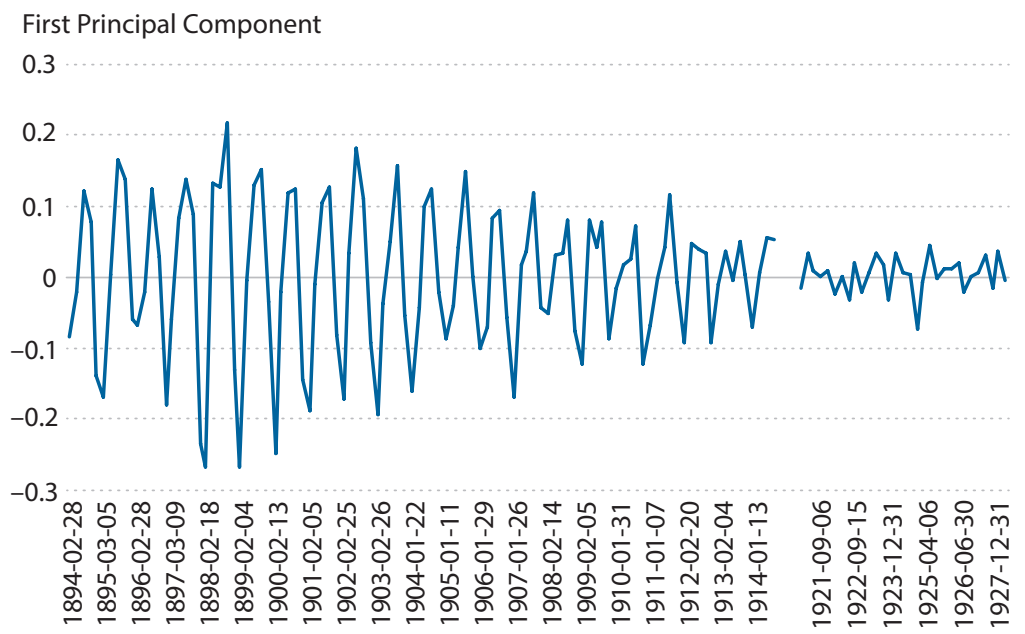

NOTE: The figure plots the first principal component of changes between reporting dates in the ratio of deposits due from other national banks to total assets for country national banks.

SOURCE: National bank data through 1910: Weber (2000). National bank data after 1910: U.S. Office of the Comptroller of the Currency (1917-28).

Figure 3

Short-Term Borrowing by Country National Banks, 1894-1914 and 1921-28

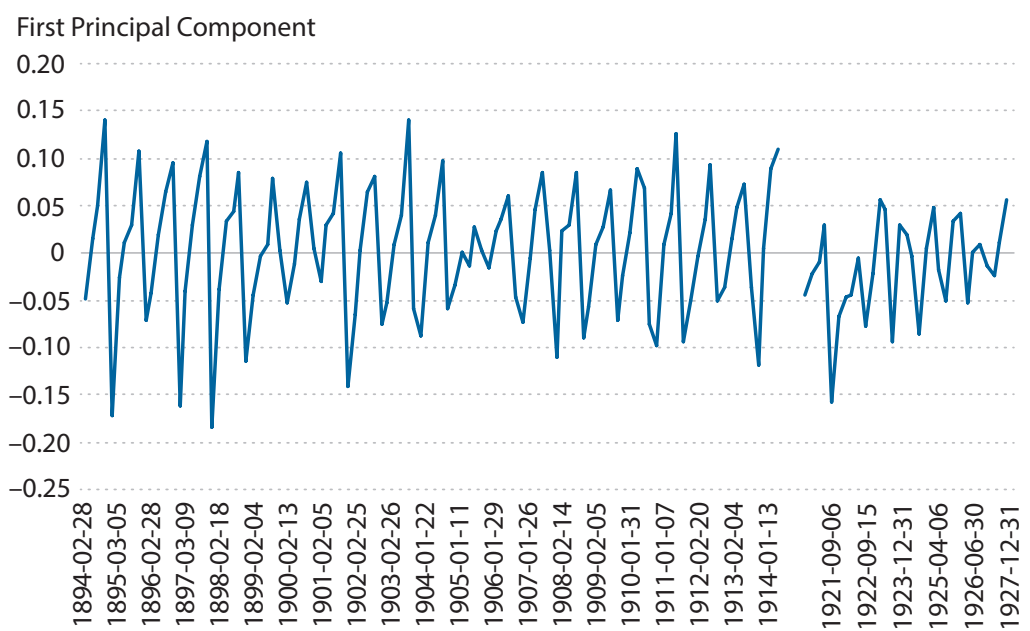

NOTE: The figure plots the first principal component of changes between reporting dates in the ratio of short-term borrowing ("bills discounted" and "bills payable") to total assets for country national banks.

SOURCE: National bank data through 1910: Weber (2000). National bank data after 1910: U.S. Office of the Comptroller of the Currency (1917-28). 


\section{Carlson and Wheelock}

Figure 4

Reserve Flows of Country National Banks, 1894-1914 and 1921-28

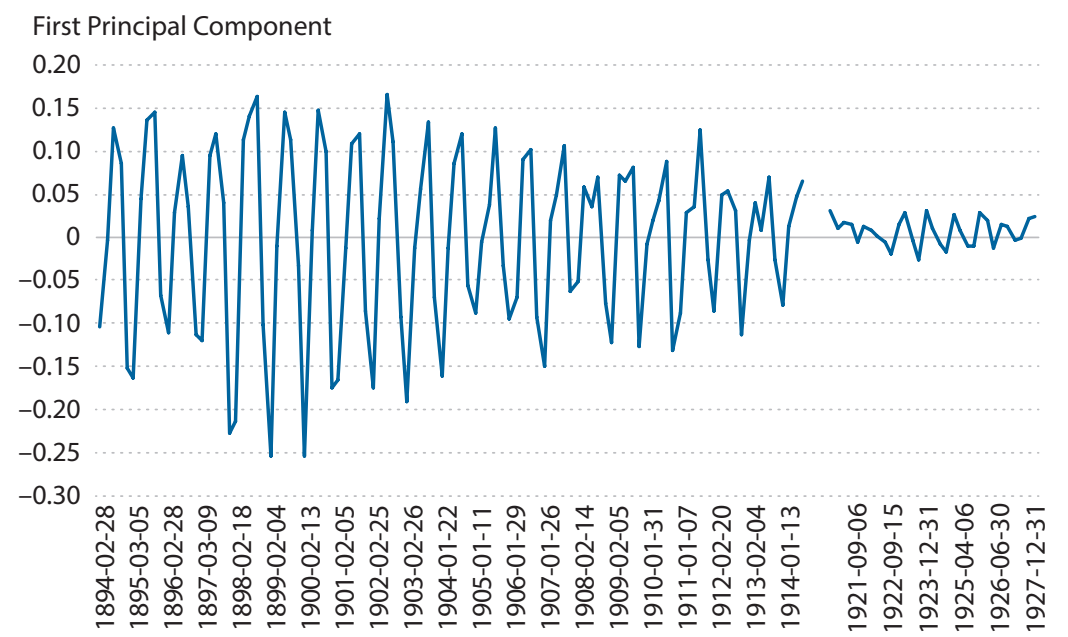

NOTE: The figure plots the first principal component of changes between reporting dates in the ratio of reserves to total assets for country national banks, where reserves is the sum of vault cash, cash items in the process of collection, and deposits with reserve agents.

SOURCE: National bank data through 1910: Weber (2000). National bank data after 1910: U.S. Office of the Comptroller of the Currency (1917-28).

Figure 5

Non-Bank Deposit Flows of Country National Banks, 1894-1914 and 1921-28

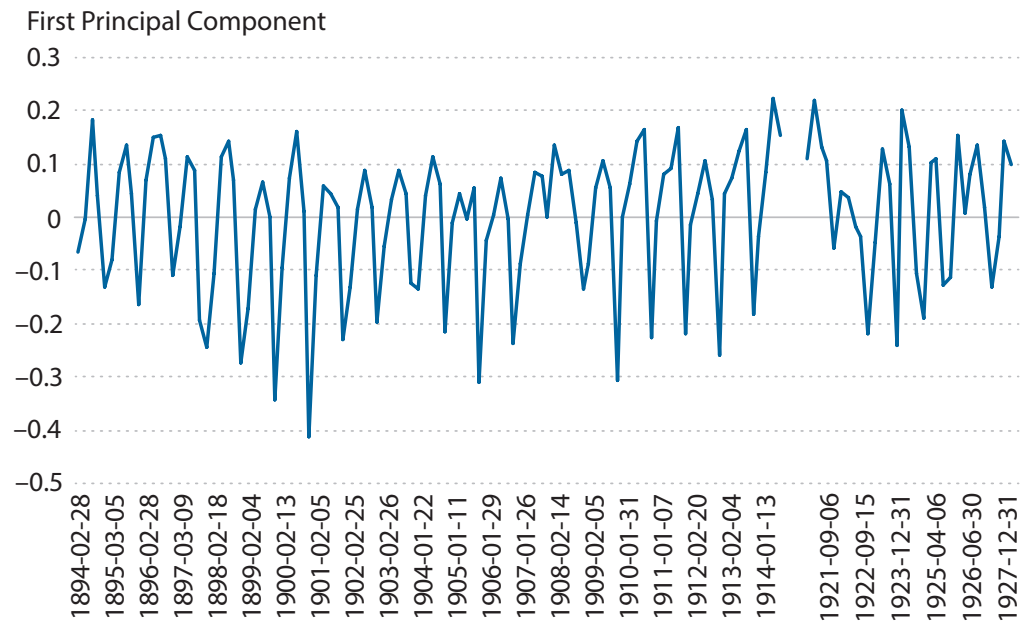

NOTE: The figure plots the first principal component of changes between reporting dates in the ratio of deposits of individuals to total assets for country national banks, where deposits of individuals includes deposits of firms, households, and state and local governments, but does not include federal government deposits or interbank deposits.

SOURCE: National bank data through 1910: Weber (2000). National bank data after 1910: U.S. Office of the Comptroller of the Currency (1917-28). 


\section{Figure 6}

\section{Changes in Total Loans of Country National Banks, 1894-1914 and 1921-1928}

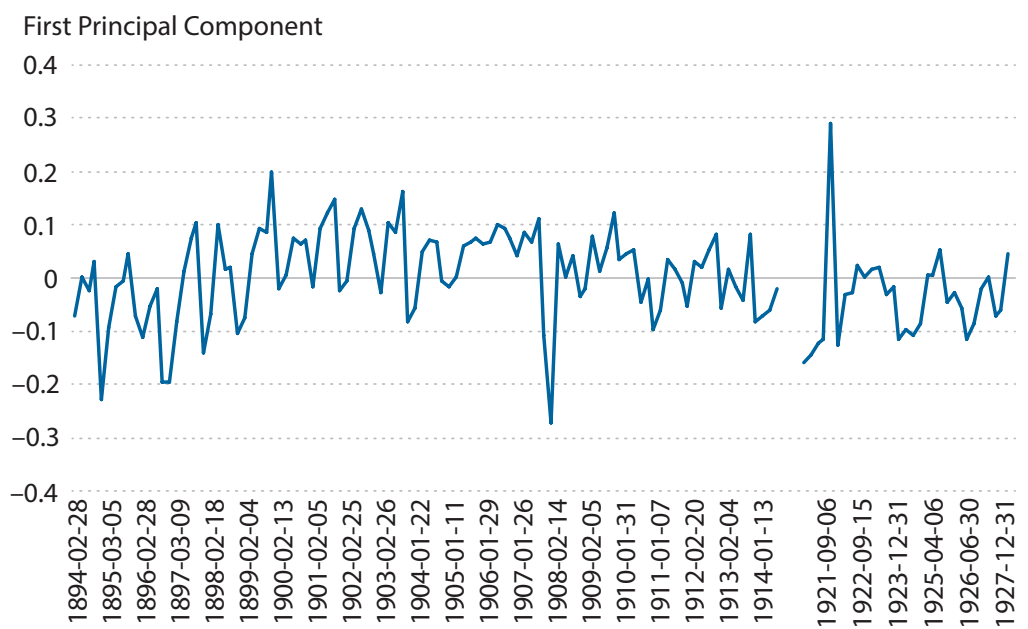

NOTE: The figure plots the first principal component between reporting dates in the ratio of loans to total assets for country national banks.

SOURCE: National bank data through 1910: Weber (2000). National bank data after 1910: U.S. Office of the Comptroller of the Currency (1917-28).

Figure 5 plots the first principal component of changes in the deposits of individuals (including firms and state and local governments, but not the federal government or interbank deposits), scaled by total assets-that is, deposits/assets, for country national banks. The principal component exhibits a highly seasonal pattern, with little evidence of a change in intra-year variation in the 1920s. Figure 6 plots the first principal component of changes in the loansto-assets ratio for country national banks. This principal component appears somewhat less seasonal than the principal component of changes in deposits/assets, both before 1914 and during the 1920s. Miron (1986) argues that total loans in the economy (both private loans and Federal Reserve loans) should have exhibited more seasonal variability after the Fed's founding, but that private lending should have been less seasonal. However, the intra-year variation in the first principal component of changes in loans/assets exhibits no clear evidence of a change in seasonal pattern. The relative stability of reserves/assets in the face of continued seasonal variability in deposits/assets and loans/assets during the 1920s, as well as the substantial decline in the seasonal variability in market interest rates, is consistent with the Fed having provided seasonal liquidity to the banking system. The next section provides additional evidence linking the provision of seasonal liquidity to Federal Reserve lending.

\section{Regional Patterns in Seasonal Demands and Federal Reserve Lending}

In his study for the National Monetary Commission, Kemmerer (1910) documented distinct regional differences in seasonal demands for money and credit and their effects on the 


\section{Carlson and Wheelock}

Figure 7

Short-Term Borrowing by Country Banks in the U.S. South, 1894-1914 and 1921-28

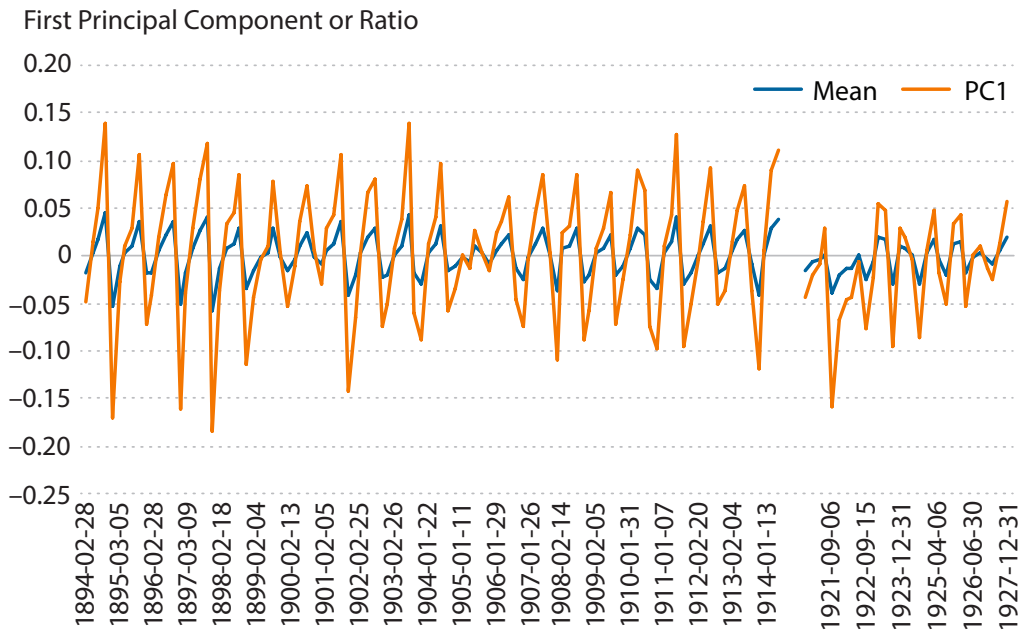

NOTE: The figure plots the first principal component of changes between reporting dates in the ratio of short-term borrowing to total assets for all country national banks ("PC1") and the mean change in the ratio for country national banks in eight southern states (Alabama, Arkansas, Georgia, Louisiana, Mississippi, North Carolina, South Carolina, and Texas) ("Mean").

SOURCE: National bank data through 1910: Weber (2000). National bank data after 1910: U.S. Office of the Comptroller of the Currency (1917-28).

size and timing of currency and payments flows through the interbank system. Kemmerer showed that movements of currency and bank reserves, both within and between different regions of the country, were large and dominated by the demands of agriculture and other activities with regular seasonal patterns. Further, he showed that regional differences in the timing and size of seasonal demands reflected differences in the size of the agricultural sector and types of commodities produced and other seasonal activities.

This subsection focuses on the regional differences in the seasonal patterns of bank balance sheets and Federal Reserve Bank lending during the 1920s. Proponents of a geographically decentralized system argued that a monolithic central bank would not be responsive to the needs of different parts of the country. Hence, the Federal Reserve System was designed as a confederation of regional Reserve Banks that would each provide for the currency and credit requirements of its own district and thereby take pressure off of the interbank system to move funds between regions:

The very essence of the new plan is intended to meet the condition which in the past has caused chief trouble by eliminating this necessity of interdependence between districts. The Federal Reserve Act will presumably afford a means of making each district selfsupporting in a credit way so that assuming the plan to work as it is expected to work the need for mutual seasonal aid and shipments of currency will be minimized. (Reserve Bank Organization Committee, 1914, p. 15) 
Carlson and Wheelock

\section{Figure 8}

Changes in Total Loans of Country National Banks in the U.S. South, 1894-1914 and 1921-28

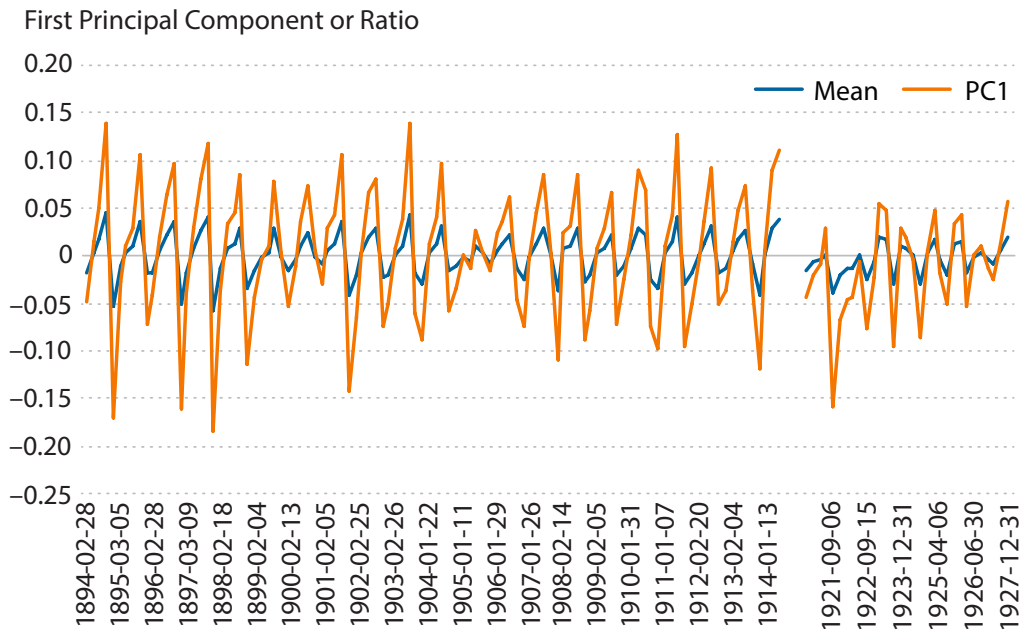

NOTE: The figure plots the first principal component of changes between reporting dates in the ratio of loans to total assets for all country national banks ("PC1") and the mean change in the ratio for country national banks in eight southern states (Alabama, Arkansas, Georgia, Louisiana, Mississippi, North Carolina, South Carolina, and Texas) ("Mean").

SOURCE: National bank data through 1910: Weber (2000). National bank data after 1910: U.S. Office of the Comptroller of the Currency (1917-28).

Figure 9

Reserve Flows of Country National Banks in the U.S. South, 1894-1914 and 1921-1928

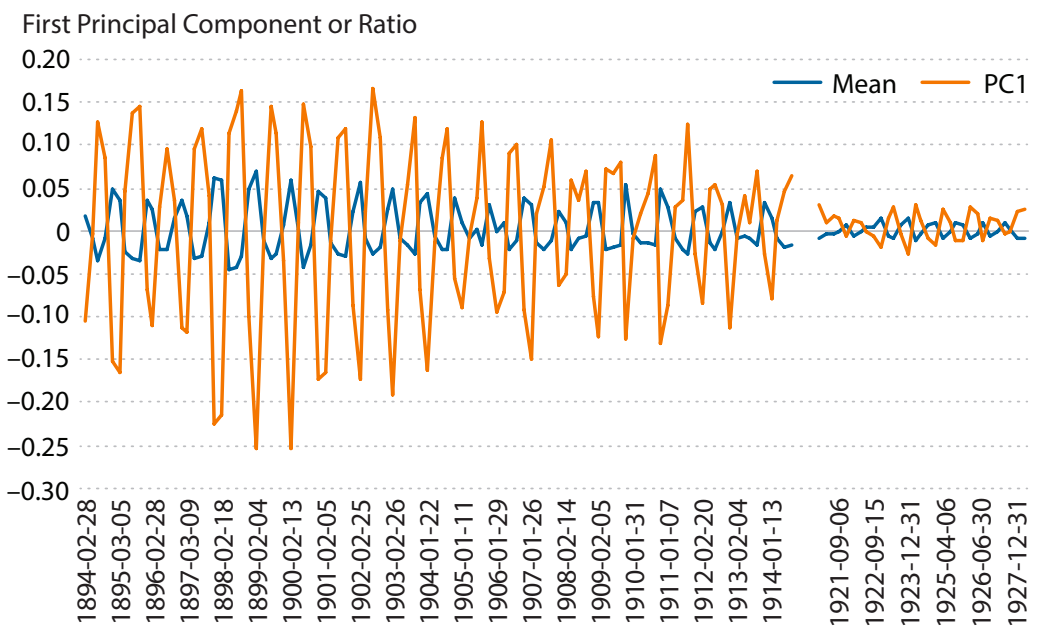

NOTE: The figure plots the first principal component of changes between reporting dates in the ratio of reserves to total assets for all country national banks ("PC1") and the mean change in the ratio for country national banks in eight southern states (Alabama, Arkansas, Georgia, Louisiana, Mississippi, North Carolina, South Carolina, and Texas) ("Mean").

SOURCE: National bank data through 1910: Weber (2000). National bank data after 1910: U.S. Office of the Comptroller of the Currency (1917-28). 


\section{Carlson and Wheelock}

If the System worked as the organizers intended, the seasonal lending of the different Reserve Banks should have mimicked the seasonal patterns in liquidity demands of their districts. Further, evidence that the Fed's lending coincided with seasonal demands would seem to indicate that the Fed, rather than something else, was responsible for the easing of seasonal pressures on money markets and the interbank system.

Before the Fed was established, country banks borrowed short-term funds mainly from their correspondents. As shown in Figure 3, the short-term borrowing of country national banks exhibited a decidedly seasonal pattern. It was also highly concentrated geographically. The states that load most strongly on the first principal component of changes in borrowing (scaled by total assets) — that is, borrowing/assets-between reporting dates are eight southern states: Alabama, Arkansas, Georgia, Louisiana, Mississippi, North Carolina, South Carolina, and Texas. Figure 7 plots the average change in borrowing/assets across these eight states alongside the first principal component shown in Figure 3. Clearly, the seasonal pattern of the principal component mimicked the short-term borrowing by banks in those eight states. According to Redenius and Weiman (2011), the dominance of a single crop-cotton-and the particularly important role of local banks (and by extension their correspondents) in financing the marketing of the cotton crop gave the South a "voracious appetite" for interbank loans and an outsized impact on the "systemic seasonality" of U.S. liquidity demand. Citing data from Kemmerer (1910), Redenius and Weiman (2011) note that southern banks, despite accounting for less than 4 percent of total U.S. bank assets in 1900, accounted for 25 percent of the outflow of cash from the New York money market in the fall and some 30 percent of the flow into New York in the late winter and early spring. By contrast, in the Midwest and other farming regions, greater diversity in the mix of crops and animal production smoothed seasonal demands somewhat, while a more efficient distribution system placed less demand on local banks for financing crop marketing.

Figure 8 plots the first principal component of the change in loans/assets for country national banks alongside the average values for the eight southern states. In the South, loan demand peaked during the fall harvest and coincided with the national peak, as reflected in the seasonal pattern of the first principal component. Figure 9 plots the first principal component of the change in reserves/assets along with the averages for the eight southern states. Clearly, the diminished seasonal volatility evident in the principal component of changes in reserves/assets in the 1920s mirrors reduced seasonal volatility in the data for country national banks in the South.

\section{Federal Reserve Bank Lending Patterns}

The Federal Reserve Act specified that a committee, composed of the Secretaries of the Treasury and Agriculture and the Comptroller of the Currency, would set the boundaries of the Federal Reserve districts and choose the cities for Reserve Banks. Relative to the total volume of bank assets of the region, the South was awarded a disproportionate number of Reserve Banks. 11 The cotton states were divided among the Richmond, Atlanta, St. Louis, and Dallas districts. 
Carlson and Wheelock

年

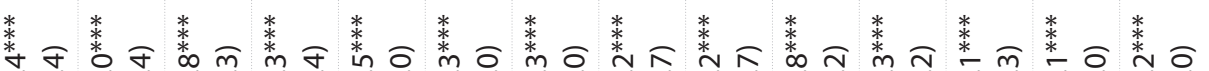
స

水

粦

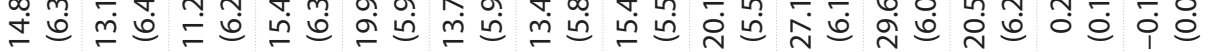

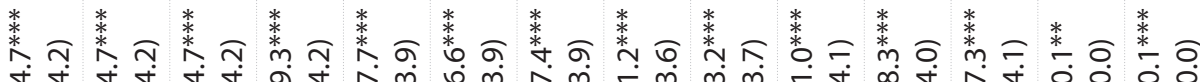

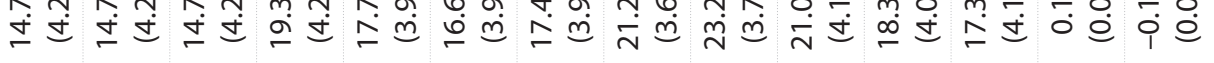

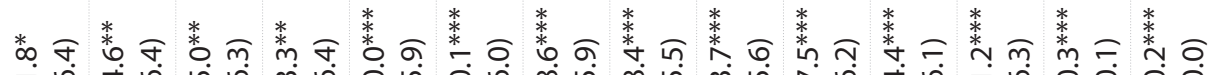

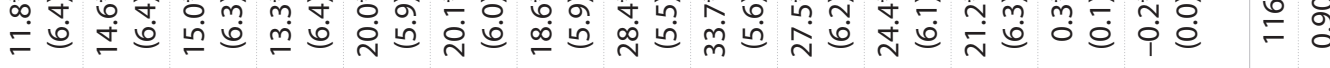

+ โก

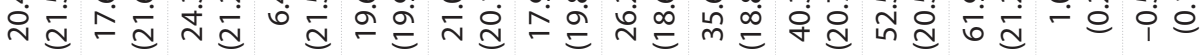

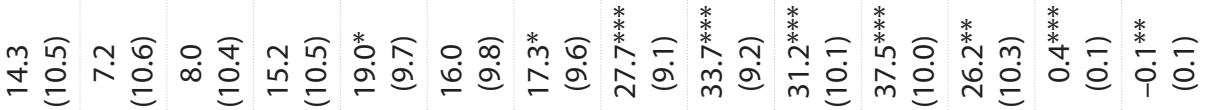

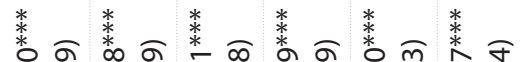

药 $\widehat{N}$

ำ

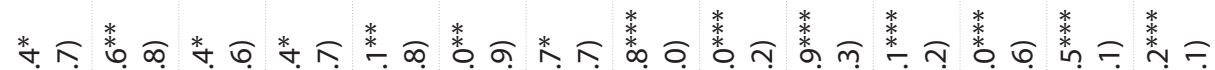

过峲穵

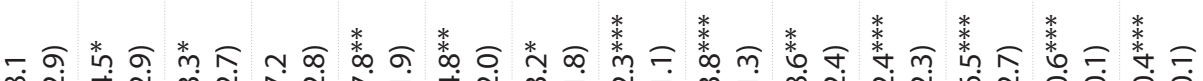

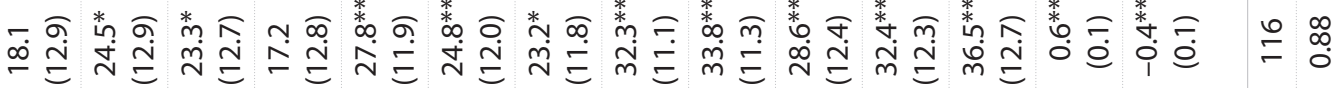

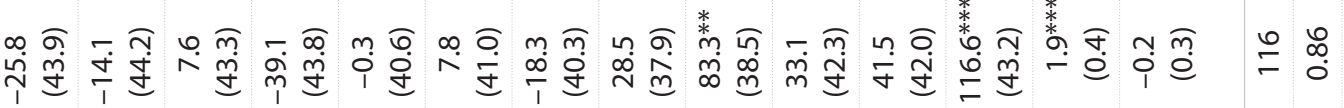

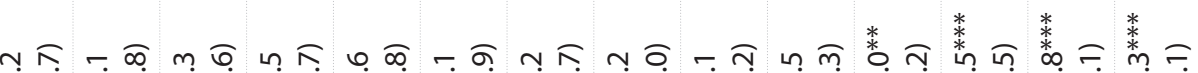

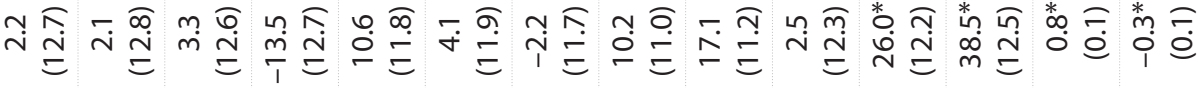

$\stackrel{\tilde{\omega}}{\underline{\omega}}$

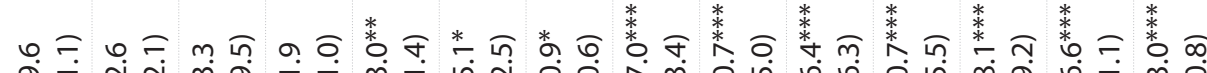

$\stackrel{2}{\stackrel{2}{-}}$

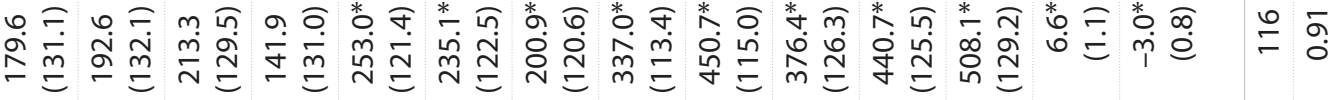

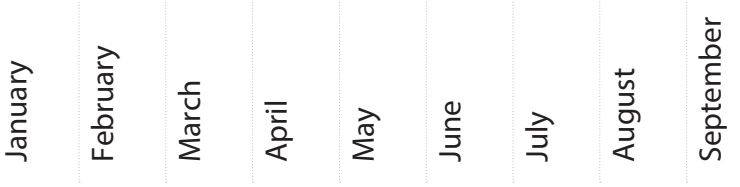

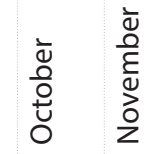

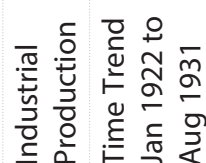

$\stackrel{\circ}{=} \overline{0}$

$\stackrel{0}{=} \infty$

$\because \infty$

$\stackrel{0}{\simeq} \infty$

$\stackrel{0}{=} \stackrel{0}{0}$

$\stackrel{\substack{0 \\ \hdashline}}{0}$

$\because \bar{c}$

$\stackrel{\circ}{=}$

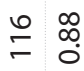

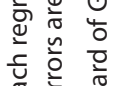

$\stackrel{\square}{\leq} \frac{0}{0}$

造

畜覀过

证

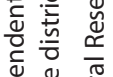

के

क्ष

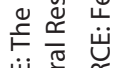




\section{Carlson and Wheelock}

Figure 10

Seasonal Patterns in Federal Reserve Credit, 1922-31

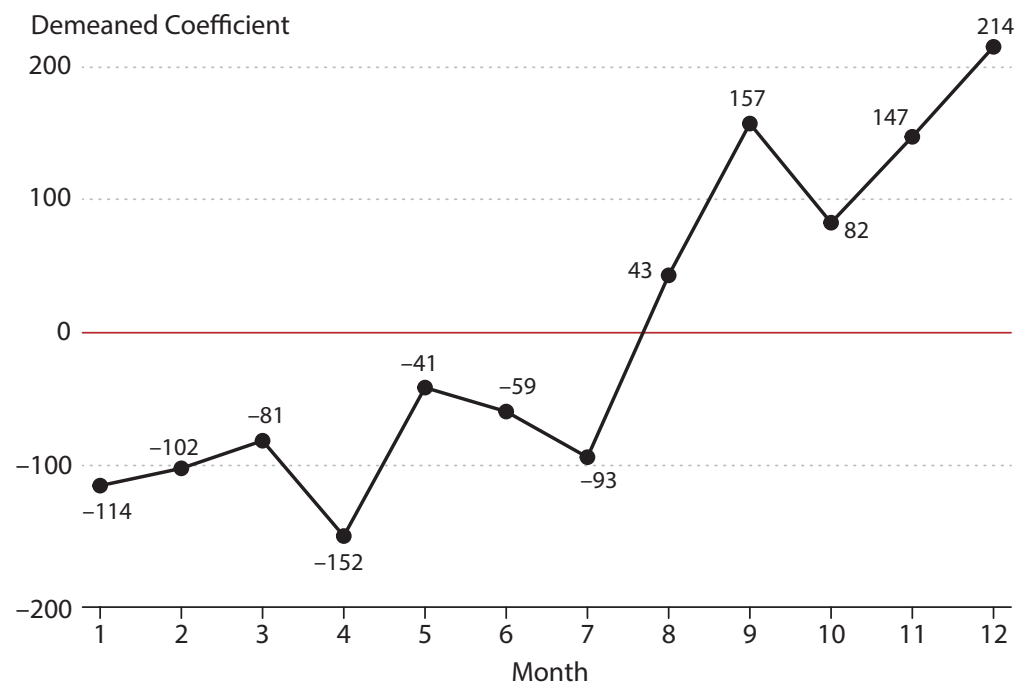

NOTE: The figure plots the demeaned coefficients on monthly dummy variables from a regression of Federal Reserve credit (sum of discount window loans and bankers' acceptance holdings) on the dummy variables, an index of industrial production (relative to its level in January 1915), and a time trend.

SOURCE: Federal Reserve Credit: Board of Governors of the Federal Reserve System (1943). Industrial Production: Miron and Romer (1989).

If the Federal Reserve Banks provided the seasonal accommodation that the Fed's founders intended, we would expect to find differences in the seasonal patterns of loans supplied by individual Reserve Banks reflected in differences in the timing of seasonal demands for loans and currency in the different regions of the country. The Federal Reserve Act authorized the Reserve Banks to rediscount short-term commercial and agricultural paper (i.e., bank loans) and to purchase bankers' acceptances (also known as "bills"). In practice, each Reserve Bank set a discount rate and schedule of bill buying rates and purchased the paper offered to them at those rates. $\frac{12}{}$ Discount and bill buying rates were not changed frequently or on a seasonal schedule. Hence, seasonal fluctuations in Federal Reserve credit outstanding were largely driven by demand (Wheelock, 1992).

Table 1 reports coefficients from regressions of Federal Reserve credit (i.e., rediscounts and purchases of bankers' acceptances) on 12 monthly dummy variables, a national index of industrial production (measured relative to January 1915) to capture business cycle effects on the demand for Federal Reserve credit, and a time trend. We estimate the regression for each Reserve Bank separately and also for the System as a whole. The coefficients from the System regression are reported in the first column and those of the individual Reserve Banks in the other columns. We estimate the regressions using monthly data for January 1922 to August 1931. We omit the early years of the System through 1921 to avoid the war years, when the Fed offered preferential discount rates on loans secured by U.S. government securities and 


\section{Figure 11}

\section{Seasonal Patterns in Federal Reserve Credit by Federal Reserve District, 1922-31}
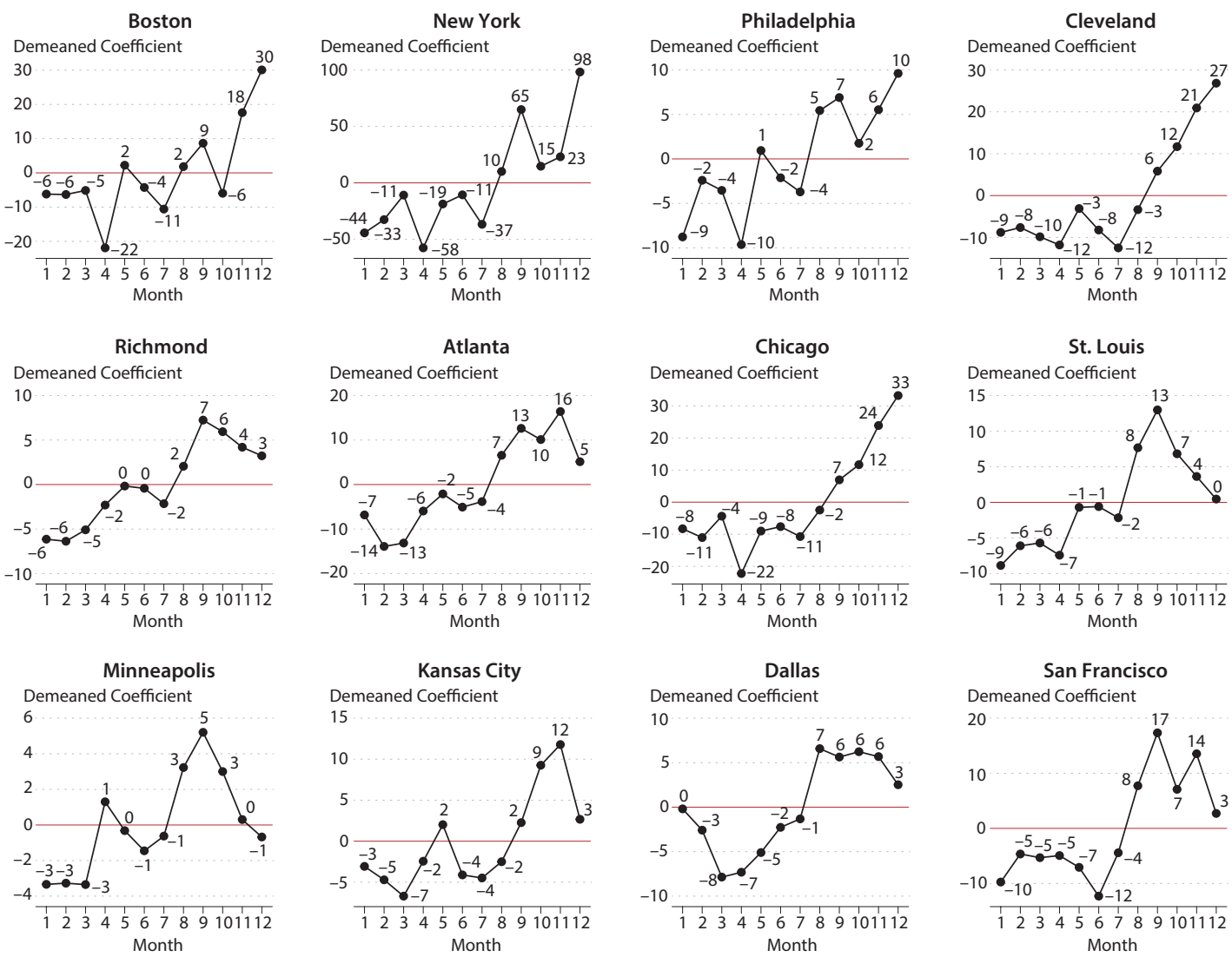

NOTE: Each panel plots for the indicated Federal Reserve district the demeaned coefficients on monthly dummy variables from a regression of Federal Reserve credit (the sum of discount window loans and bankers' acceptance holdings) on the dummy variables, an index of industrial production (relative to its level in January 1915), and a time trend.

SOURCE: Federal Reserve Credit: Board of Governors of the Federal Reserve System (1943). Industrial Production: Miron and Romer (1989).

those loans dominated the Fed's lending. We end the sample in August 1931 to avoid the effects of a major banking panic that began in September 1931.

As shown in Table 1, the coefficients on the monthly dummies indicate notable seasonal patterns in Fed lending and tend to be larger toward the end of the year. The coefficient on the December dummy variable is the largest of the monthly dummy coefficients for the System as a whole as well as for the Boston, New York, Philadelphia, Cleveland, and Chicago Reserve Banks. For the other Reserve Banks, the largest monthly coefficient is usually for an autumn month-September, October, or November.

Figure 10 plots the difference of each monthly dummy coefficient from the mean of the 12 monthly coefficients for the Federal Reserve System as a whole. At the System level, Federal Reserve credit typically exceeded the mean level during September to December and was below the mean during January to August. Seasonal peaks occurred in September and December. 


\section{Carlson and Wheelock}

Figure 11 presents similar plots for each Reserve Bank, again illustrating that Federal Reserve loans tended to peak in December in the Boston, New York, Philadelphia, Cleveland, and Chicago districts, but in earlier months in all other districts. The four districts in the Northeast had large manufacturing and financial sectors and relatively small agricultural sectors. In those districts, strong demands for currency and reserves were likely dominated by the December holiday shopping season and end-of-year payments for settlement of business and financial transactions. The Chicago District was more diverse, having large manufacturing and agricultural sectors as well as a large financial center. By contrast, the remaining districts had relatively larger farming sectors-and greater demand for harvest-related funds. Hence, the differences in the seasonal lending patterns of the Reserve Banks are broadly consistent with the differences in the timing of local demands for money and bank loans observed by Kemmerer (1910) and are evidence that the Federal Reserve was likely responsible for the substantial reduction in seasonal liquidity pressures on bank balance sheets and money markets.

\section{IMPACT ON BANK LIQUIDITY AND THE SIZE OF THE INTERBANK SYSTEM}

The reductions in the seasonal variation of flows of interbank deposits and bank reserves/ assets ratios after the founding of the Fed, as well as the size and seasonal timing of the Fed's lending, is strong evidence that the Fed accomplished the founders' goal of providing seasonal liquidity to the banking system. The Fed's founders also intended the System to largely supplant the existing interbank network of correspondent relationships. All national banks were required to join the Federal Reserve System (membership was optional for banks with state charters). Member banks were required to purchase stock in their local Federal Reserve Bank and to maintain a deposit with the Reserve Bank to satisfy their statutory reserve requirement. After a three-year transition period, deposits held with national banks in reserve cities or central reserve cities no longer counted toward a member bank's reserve requirement.

In addition to providing a ready source of liquidity to the banking system, the Federal Reserve was also intended to make the U.S. payments system more efficient. The Reserve Banks offered check clearing and other payments services to their member banks. The Fed quickly acquired a large share of the interregional check clearing market and seems to have made the clearing system more efficient (Gilbert 1998, 2000).

By providing a ready source of currency and making the payments system more efficient, the Federal Reserve likely enabled banks to hold a smaller share of their total assets in the form of vault cash. Further, an amendment to the Federal Reserve Act in 1917 specified that a member bank's full reserve requirement must be held as a deposit with a Federal Reserve Bank; member banks no longer had the option of using vault cash to meet their statutory requirement. Not surprisingly, national banks maintained substantially lower cash-to-assets ratios during the 1920s than they had during the 20 years before the Fed's founding in 1914. Figure 12 plots aggregated cash/assets for country national banks, national banks in 18 reserve cities, and national banks in the three central reserve cities on each reporting date during 1894-1914 and 1921-28. $\frac{13}{}$ Whereas national banks held vault cash equal to between 5 and 20 


\section{Figure 12}

\section{Vault Cash as a Share of Total Bank Assets, 1894-1914 and 1921-28}

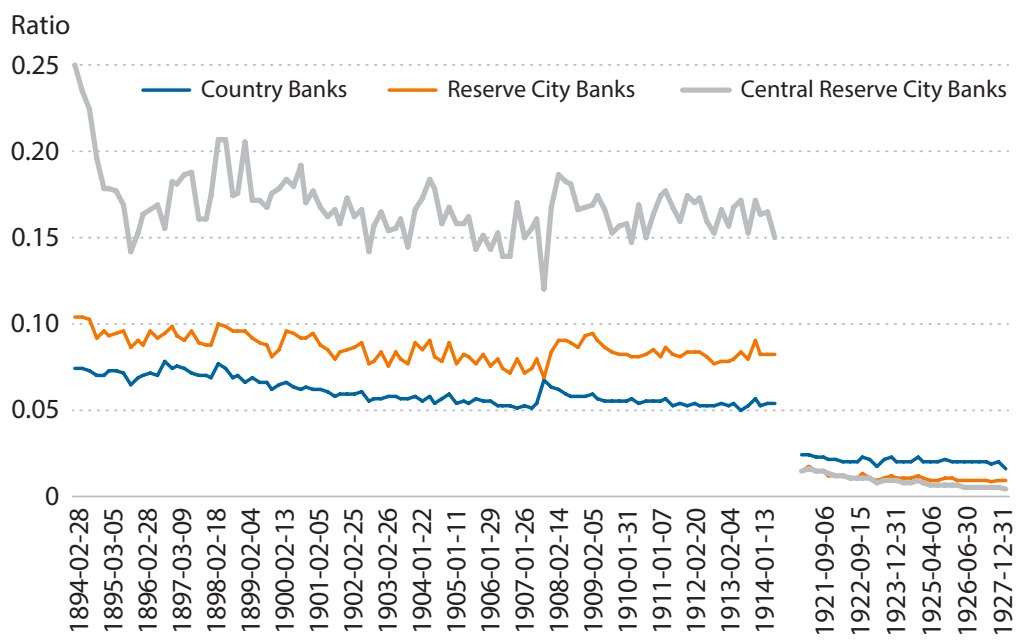

NOTE: The figure plots the ratio of vault cash to total assets for country national banks, reserve city banks, and central reserve city banks. Data for country banks are aggregated across all U.S. states; data for reserve city banks are aggregated across 18 long-time reserve cities; and data for central reserve cities are aggregated across the three central reserve cities (New York City, Chicago, and St. Louis). St. Louis is treated as a central reserve city throughout the period even though its designation was changed to reserve city in 1922.

SOURCE: National bank data through 1910: Weber (2000). National bank data after 1910: U.S. Office of the Comptroller of the Currency (1917-28).

percent of their total assets during the 20 years before the founding of the Fed, during the 1920s, vault cash comprised 2.5 percent or less of their total assets.

National banks also held much lower levels of interbank deposits during the 1920s, as shown in Figure 13. The share of total country bank assets held in the form of deposits due from other national banks, shown in Panel A, declined from an average of 12.6 percent during 1894-1914 to just 5.7 percent during 1921-28. For national banks in 18 reserve cities, the percentage of assets held as deposits due from other national banks, shown in Panel B, fell from an average of 15.6 percent during 1894-1914 to just 4.3 percent during 1921-28. At the same time, reserve city banks saw a decline in the volume of their deposits due to other national banks, from 14.2 percent to 6.9 percent (relative to their total assets). 14 Similarly, for central reserve city banks, deposits due to other national banks, shown in Panel C, declined from 22.5 percent to 7.5 percent (relative to total central reserve city bank assets). Thus, the Fed's founders appear to have accomplished their goal of shrinking the private interbank market. 15

Figure 14 presents additional information indicating that national banks were generally less liquid in the 1920s than they had been before the founding of the Fed. For each class of national bank, the figure plots a measure of reserves consisting of vault cash, cash items in the process of collection, and deposits with reserve agents. As Figure 14 shows, national banks held substantially lower reserves/assets ratios during the 1920s than they had during the 20 


\section{Carlson and Wheelock}

\section{Figure 13}

Interbank Deposits, 1894-1914 and 1921-28
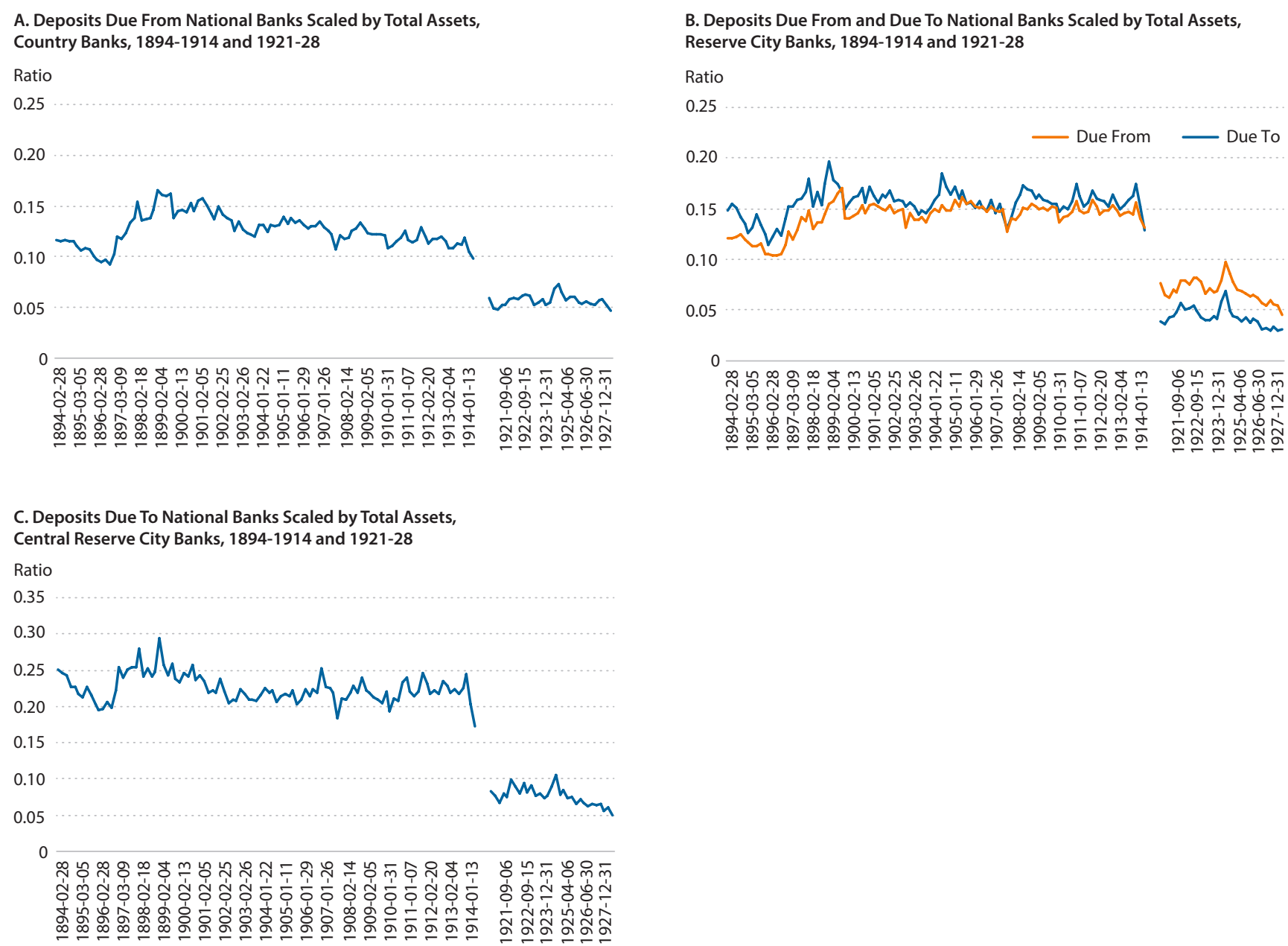

NOTE: Data for country banks are aggregated across all U.S. states; data for reserve city banks are aggregated across 18 long-time reserve cities; and data for central reserve cities are aggregated across the three central reserve cities (New York City, Chicago, and St. Louis). St. Louis is treated as a central reserve city throughout the period even though its designation was changed to reserve city in 1922.

SOURCE: National bank data through 1910: Weber (2000). National bank data after 1910: U.S. Office of the Comptroller of the Currency (1917-28).

years prior to the Fed's establishment. A portion of the decline was undoubtedly due to reductions in the required reserve ratios applied to national banks in 1913 and 1917. However, Carlson and Wheelock (2016b) show that, as a share of total assets, national banks held somewhat lower levels of reserves in excess of legal requirements in the 1920s than they had prior to $1914 . \underline{16}$ Conceivably, banks responded to the presence of the Fed-specifically to its promise to supply liquidity as needed-by holding less liquidity themselves. In effect, by enabling or encouraging banks to devote larger shares of their balance sheets to relatively illiquid but higher-earning assets, the presence of the Fed may have increased the need for a lender of 


\section{Figure 14}

\section{Reserve Ratios, 1894-1914 and 1921-28}

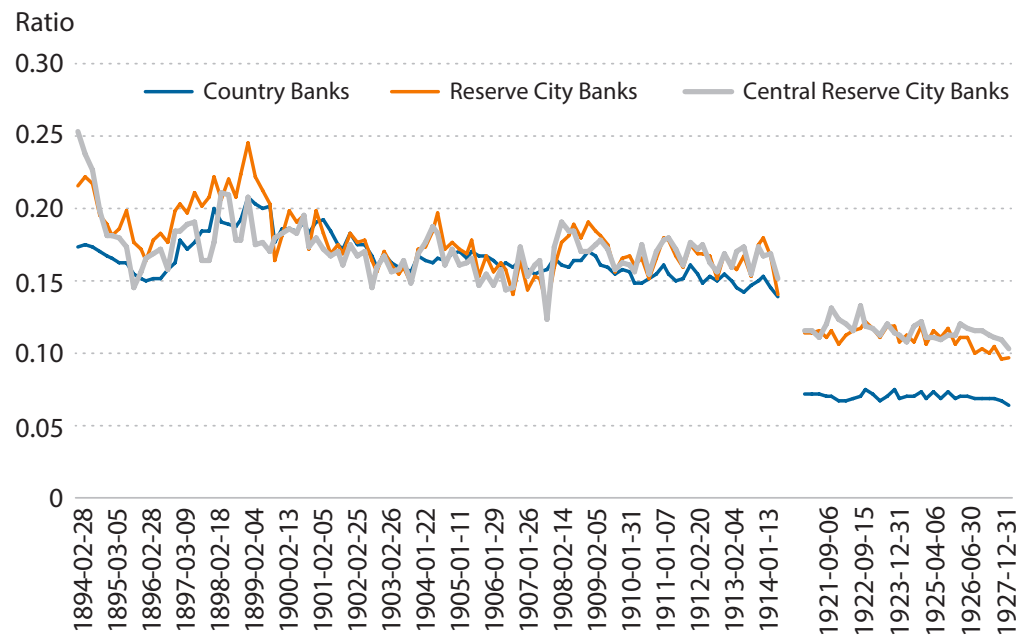

NOTE: The figure plots the ratio of reserves to total assets for banks in each tier group, where reserves are the sum of vault cash, cash items in the process of collection, and deposits with reserve agents. Data for country banks are aggregated across all U.S. states; data for reserve city banks are aggregated across 18 long-time reserve cities; and data for central reserve cities are aggregated across the three central reserve cities (New York City, Chicago, and St. Louis). St. Louis is treated as a central reserve city throughout the period even though its designation was changed to reserve city in 1922.

SOURCE: National bank data through 1910: Weber (2000). National bank data after 1910: U.S. Office of the Comptroller of the Currency (1917-28).

last resort. Ultimately, therefore, whether the Fed would be successful in preventing banking panics, and thus achieving the main objective of the System's founders, would depend on how well the Fed performed as a lender of last resort.

\section{Impacts on Bank Liabilities, Capital, and Lending}

As noted previously, before the founding of the Fed, country banks often borrowed for short periods from their correspondents, particularly at times of the year when local demands for currency and loans were at their highest. Reserve city banks generally borrowed less frequently than country banks, and central reserve city banks hardly borrowed at all. 17 Figure 15 plots the short-term borrowing of banks in each class of national banks (scaled by their total assets). Short-term borrowing was never large in the aggregate, even for country banks. Over the 20 years prior to the establishment of the Fed, borrowing approached 2 percent of country bank assets only during banking panics in 1907 and 1914. Banks tended to borrow more during the 1920s, mostly at the Fed's discount window. 18 During World War I and for several months afterward, the Fed offered a preferential discount rate on loans secured by U.S. government bonds, and banks borrowed heavily from the Fed. The preferential rate was eliminated, and Reserve Banks hiked their discount rates sharply in 1920-21. Although the level of borrowing then fell, relative to total bank assets, borrowing was considerably higher 


\section{Carlson and Wheelock}

Figure 15

\section{Short-Term Borrowing Scaled by Total Assets, 1894-1914 and 1921-28}

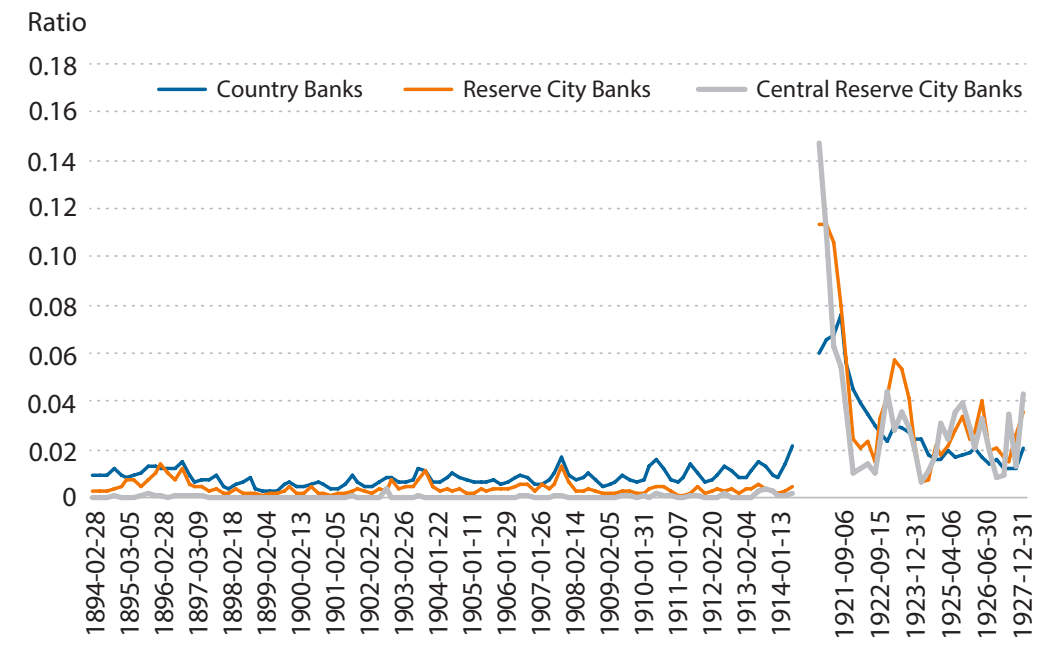

NOTE: The figure plots the ratio of short-term borrowing to total assets for banks in each tier group. Data for country banks are aggregated across all U.S. states; data for reserve city banks are aggregated across 18 long-time reserve cities; and data for central reserve cities are aggregated across the three central reserve cities (New York City, Chicago, and St. Louis). St. Louis is treated as a central reserve city throughout the period even though its designation was changed to reserve city in 1922.

SOURCE: National bank data through 1910: Weber (2000). National bank data after 1910: U.S. Office of the Comptroller of the Currency (1917-28).

during the remainder of the 1920s, especially for reserve city and central reserve city banks, than it had been before 1914 .

While the Federal Reserve Act changed the level and structure of reserve requirements imposed on banks that became members of the Federal Reserve System, the act did not change their capital requirements (except by requiring state-chartered banks that joined the System to conform with national bank requirements). At the time, federal statutes specified minimum capital levels for national banks based on the size of the city in which a bank was located, but did not specify minimum capital-to-assets ratios (or, equivalently, maximum leverage ratios). $\underline{19}$ Many states set even lower minimums for their state-chartered banks, which apparently was one reason why few state-chartered banks elected initially to join the Federal Reserve System (White, 1983, pp. 14-23). As shown in Figure 16, the aggregate capital/assets ratio of country national banks declined from over 0.35 (35 percent) in 1896 to 0.20 in 1914. By 1921, the ratio had fallen to 0.15 , or less than half the level of 1896 . The aggregate capital/assets ratios for reserve city and central reserve city banks also declined over time and ranged between 0.10 and 0.15 during the 1920s. The declines for reserve city and central reserve city banks were less dramatic than those for country banks, however, with less of a discrete decline between the pre-Fed period and the 1920s. Hence, it is unclear whether the Fed's founding explains the lower national bank capital/assets ratios in the 1920 s. 


\section{Figure 16}

\section{Bank Equity Scaled by Total Assets, 1894-1914 and 1921-28}

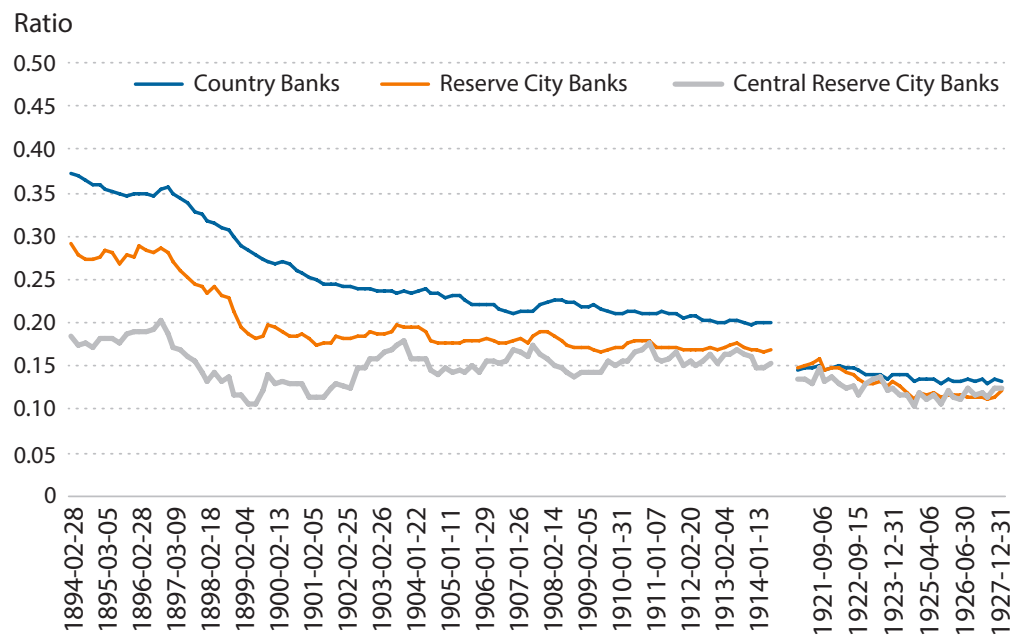

NOTE: The figure plots the ratio of equity (paid in capital, surplus, and undistributed profits) to total assets for banks in each tier group. Data for country banks are aggregated across all U.S. states; data for reserve city banks are aggregated across 18 long-time reserve cities; and data for central reserve cities are aggregated across the three central reserve cities (New York City, Chicago, and St. Louis). St. Louis is treated as a central reserve city throughout the period even though its designation was changed to reserve city in 1922.

SOURCE: National bank data through 1910: Weber (2000). National bank data after 1910: U.S. Office of the Comptroller of the Currency (1917-28).

Whereas bank capital/assets ratios declined between the pre-Fed period and the 1920s, the deposits/assets ratios rose, at least among country national banks, as shown in Panel A of Figure 17. $\stackrel{20}{ }$ Reserve city banks experienced a much smaller increase in deposits/assets ratios, while central reserve city banks saw a decline. However, both reserve city and central reserve city banks saw substantial increases in deposits/assets ratios exclusive of their deposits due to national banks, as shown in Panel B. The Fed's promise to provide the liquidity needed to meet their customers' demand for cash, as well as improved efficiency of check collection (Gilbert 1998, 2000), probably made banks more willing to offer demand deposits and led to higher deposits/assets ratios.

Finally, Figure 18 plots data on loans/assets ratios for each of the three classes of national banks. There are no obvious patterns. Loans generally ranged between 50 and 60 percent of total assets for each class during both the pre-Fed period and 1920s. The Fed's founding did not produce an obvious change in the shares of national bank assets composed of loans. $\frac{21}{\text { Instead, }}$ national banks devoted larger shares of their portfolios to various types of securities. During the 20 years before the Fed was established, securities typically comprised about 15 percent of total national bank assets. However, in the 1920s, they usually exceeded 20 percent of assets. $\underline{22}$

In sum, the presence of the Fed had its largest impact on banks' demand for liquid assets and interbank balances. Relative to their total assets, national banks held substantially lower 


\section{Carlson and Wheelock}

Figure 17

Deposits Scaled by Total Assets, 1894-1914 and 1921-28

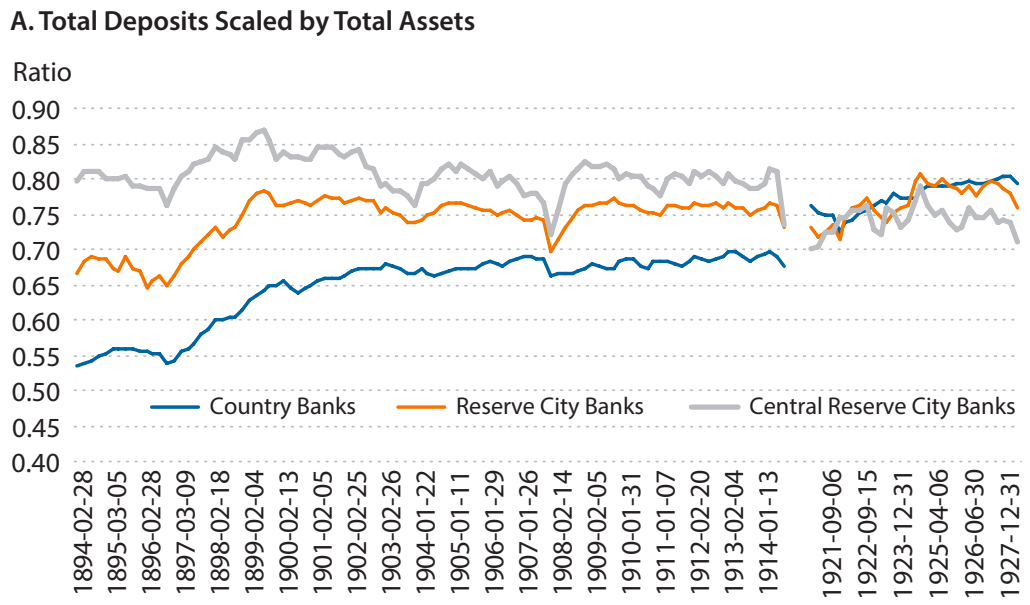

B. Deposits Exclusive of Deposits Due To National Banks Scaled by Total Assets

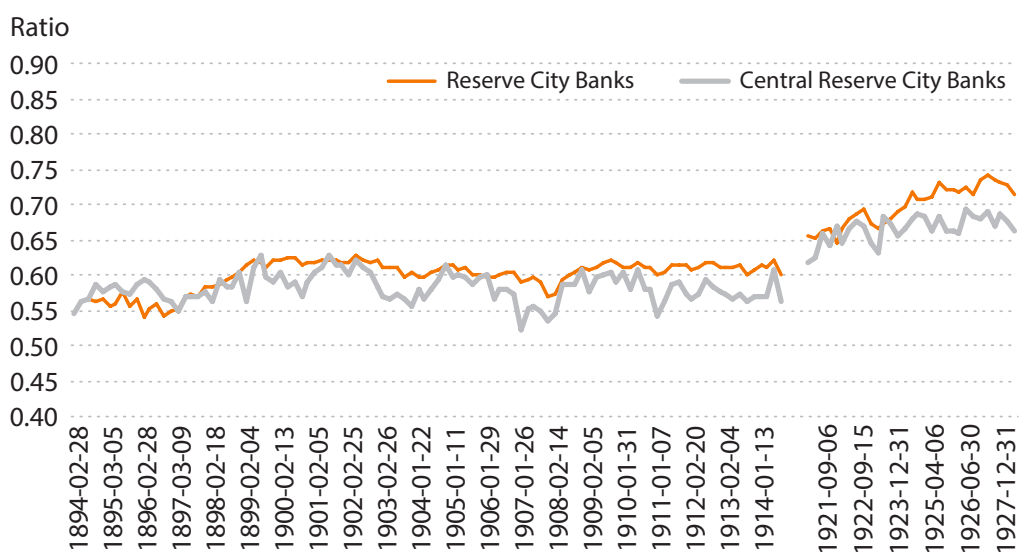

NOTE: The figure plots the ratio of total deposits to total assets for banks in each tier group (Panel $A$ ) and the ratio of deposits exclusive of deposits due to other national banks to total assets for reserve city and central reserve city banks (Panel B). Data for country banks are aggregated across all U.S. states; data for reserve city banks are aggregated across 18 long-time reserve cities; and data for central reserve cities are aggregated across the three central reserve cities (New York City, Chicago, and St. Louis). St. Louis is treated as a central reserve city throughout the period even though its designation was changed to reserve city in 1922.

SOURCE: National bank data through 1910: Weber (2000). National bank data after 1910: U.S. Office of the Comptroller of the Currency (1917-28).

levels of reserves and interbank deposits in the 1920s than they had before the Fed's founding. National banks also had higher deposits/assets ratios (excluding interbank deposits) and lower capital/assets ratios during the 1920s. Although we have not formally tested whether the presence of the Fed caused or contributed to these changes in national bank portfolios, they are consistent with the idea that the Fed's presence gave banks confidence to assume greater liquidity risk and leverage. 


\section{Figure 18}

\section{Total Loans Scaled by Total Assets, 1894-1914 and 1921-28}

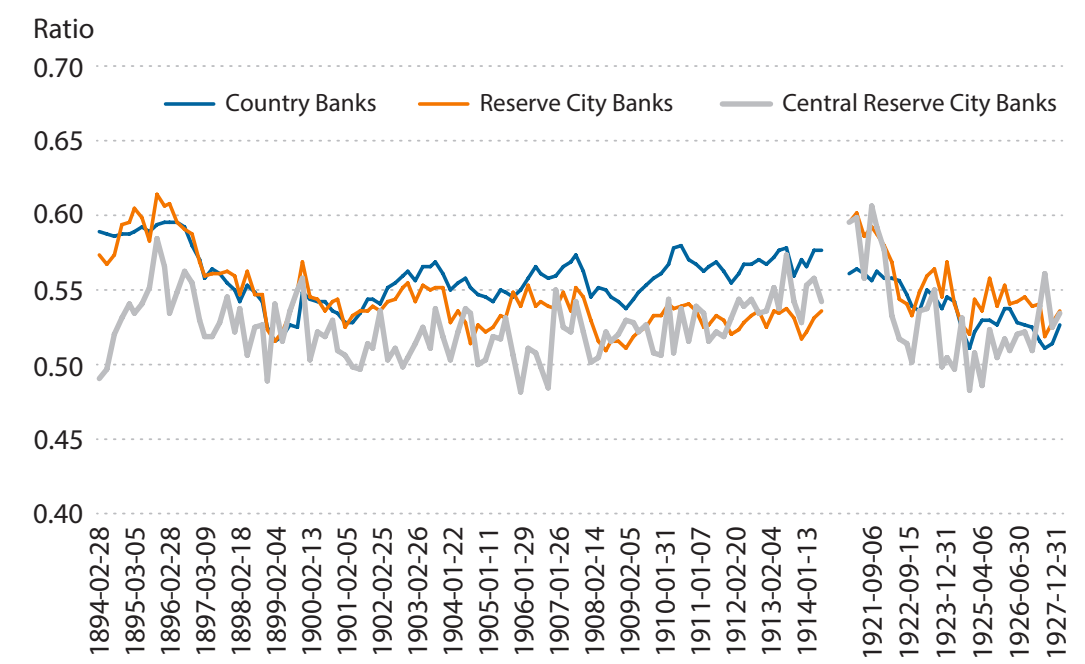

NOTE: The figure plots the ratio of loans to total assets for banks in each tier group. Data for country banks are aggregated across all U.S. states; data for reserve city banks are aggregated across 18 long-time reserve cities; and data for central reserve cities are aggregated across the three central reserve cities (New York City, Chicago, and St. Louis). St. Louis is treated as a central reserve city throughout the period even though its designation was changed to reserve city in 1922.

SOURCE: National bank data through 1910: Weber (2000). National bank data after 1910: U.S. Office of the Comptroller of the Currency (1917-28).

\section{CONCLUSION}

The establishment of the Federal Reserve System greatly altered the operating environment for U.S. banks. The Federal Reserve Act changed the structure of reserve requirements imposed on banks that joined the Federal Reserve System, created a new currency and payments provider, and introduced a lender of last resort. The System's founders sought to protect the banking system from banking panics, which they attributed largely to the nation's "inelastic currency" and the fragility of the interbank system. Accordingly, the Fed was designed to hold the reserves of its member banks, supply currency and reserves to meet recurring and extraordinary demands, and provide check clearing and other payments services.

Our analysis of national bank balance sheet data provides new evidence of reduced seasonal liquidity pressures on the banking system after the founding of the Fed. Seasonal movements in interbank deposits and country national bank borrowing and reserve/asset ratios were considerably smaller during the 1920s than they had been over the two decades preceding the Fed's establishment. At the same time, Federal Reserve lending was markedly seasonal, and seasonal peaks in lending by the individual Reserve Banks coincided with seasonal peaks in liquidity demands in their districts. Thus, the evidence from national bank data and Federal Reserve lending patterns, coupled with evidence of reduced seasonal pressures in money mar- 


\section{Carlson and Wheelock}

kets, suggests strongly that the System's founders accomplished their goal of accommodating seasonal liquidity demands.

In addition to exhibiting reduced seasonality, the correspondent deposits and liquid reserves of national banks were also much smaller relative to total bank assets during the 1920s than they had been before the founding of the Fed. Banks also relied more heavily on deposits for funding and had somewhat lower average equity/asset ratios in the 1920s. By encouraging banks to be less liquid themselves, it was especially important that the Fed perform as the System's founders had intended and provide a liquidity backstop in the event of a panic. That is, the presence of a lender of last resort encouraged banks to act in ways that increased the likelihood that the support of a lender of last resort would be needed.

The absence of significant banking panics throughout the 1920s, despite large numbers of bank failures, was viewed as important evidence that the problem of banking panics had indeed been solved. Congress awarded this apparent success in 1927 by making the charters of the 12 Federal Reserve Banks, which the Federal Reserve Act had set at 20 years, permanent. Moreover, quick action by the Federal Reserve Bank of Atlanta to stem a local banking panic in Florida in 1929 suggested that the Fed had the tools to prevent major panics of the sort that had plagued the banking system before the Fed's founding (Carlson, Mitchener, and Richardson, 2011).

Banking panics returned with a vengeance in the early 1930s, however, and the Federal Reserve proved incapable or unwilling to perform as lender of last resort on a national scale. The banking panics of the Great Depression showed that elimination of seasonal liquidity pressures was not sufficient to prevent banking panics, and the variety of responses by the individual Reserve Banks suggest that the Fed's structure inhibited a response to a nationwide crisis. $\underline{23}$ Thus, while the Fed's founders achieved their proximate goals, the banking panics of the Great Depression showed that further reforms were needed to achieve the founders' ultimate goal of ending banking panics. 


\section{NOTES}

1 See, for instance, Yellen (2016) and the Basel Committee on Banking Supervision (2016).

$\underline{2}$ For example, Bianchi (2016) examines the trade-offs associated with financial bailouts in a quantitative equilibrium model of financial crises. By easing balance sheet constraints, lender of last resort interventions can mitigate the severity of a crisis-induced recession, but bailouts generally lead to greater risk-taking and thus make economies more vulnerable to crises. However, Bianchi finds that economies are significantly less exposed to crises when lender of last resort actions are systemic and broad-based than when they are idiosyncratic and targeted.

$\underline{3}$ Bernstein, Hughson, and Weidenmier (2010) find that the volatilities of both interest rates and stock prices during the months of September and October - the two months of peak volatility during the late-nineteenth and earlytwentieth centuries-were significantly lower after the Fed's founding. However, if years of banking panics are omitted from the sample, then volatilities were similar between the pre-Fed and post-1914 years. They argue that the Fed's primary effect was to reduce liquidity risk in years when there was a business cycle turning point and financial crisis. Further, there is some debate about whether the Fed was responsible for a reduction in seasonal interest rate volatility that occurred in many countries around 1914 (see Wheelock, 1992, and the references therein).

4 A "correspondent" bank is one with whom another bank, known as the "respondent," maintains a deposit or receives services.

5 Calomiris and Gorton (1991) contend that the Fed's founders misunderstood (or mischaracterized) the causes of banking panics. Rather than being caused by random, unexpected, or seasonal withdrawals of cash from banks, Calomiris and Gorton (1991) argue that panics occurred when adverse news about the macroeconomy caused bank depositors to revise their perceptions about the risk of bank debt. Because depositors are unable to distinguish among individual bank risks, they withdrew a large volume of deposits from all banks. Calomiris and Gorton (1991) find little association between seasonal liquidity demands and the incidence of panics.

6 Banks chartered by state governments were also connected to the interbank system. State banks were subject to state-specific reserve requirements. Many state banks maintained deposits with national banks to satisfy reserve requirements or to obtain services, and some national banks held deposits with state banks. Consistent balance sheet data are not available for state-chartered banks, however, and this article is based solely on data for national banks.

7 During World War I and for several months afterward, the Federal Reserve Banks offered low discount rates on loans secured by U.S. government bonds, and member banks borrowed heavily from the Fed. The Reserve Banks increased their discount rates sharply in 1920 and borrowing dropped precipitously. By 1922, discount window lending and bank balance sheets displayed regular seasonal patterns and levels. Hence, to assess the long-run impact of the Fed, we focus on the period 1922-28 (we end our comparison period in 1928 both to avoid distortions caused by the Great Depression and because of changes in how national bank balance sheet data were reported). This article uses national bank balance sheet data for country banks aggregated at the level of states and for individual reserve and central reserve cities, which are available for 1880-1910 from the Federal Reserve Bank of Minneapolis digital archive (http://cdm16030.contentdm.oclc.org/cdm/singleitem/collection/p16030coll4/id/6/ $\underline{\mathrm{rec} / 2}$ ). For other years, the article uses data from annual reports of the Comptroller of the Currency, which are available from the Federal Reserve Bank of St. Louis (https://fraser.stlouisfed.org/title/56).

8 For each state, we calculate the net deposits due from reserve agents and other national banks as the difference between deposits due from banks and deposits due to banks. For the 1920s, deposits due from agents represent deposits that banks held with the Federal Reserve.

9 Changes in the frequency and timing of reporting dates over the sample period make it impossible to draw firm conclusions about seasonal patterns in bank balance sheets. See Carlson and Wheelock (2016a,b) for more discussion and evidence about changes in seasonal pressures on the interbank system with the establishment of the Fed.

$\underline{10}$ Short-term borrowing consisted of "bills rediscounted," that is, loans sold with recourse, and "bills payable," that is, promissory notes of the borrowing bank, and includes borrowing from Federal Reserve Banks in the 1920s.

11 See Odell and Weiman (1998) on the selection of Atlanta and Dallas for Reserve Banks, and Jaremski and Wheelock (2017) and Wheelock (2015) for discussion and analysis of the selection of Reserve Bank cities and branches and district boundaries. 


\section{Carlson and Wheelock}

12 At the time, short-term commercial and agricultural loans were typically made on a discount basis. A member bank could obtain cash or reserve deposits from the Fed by rediscounting a loan -in effect selling the loan to the Federal Reserve Bank at the Reserve Bank's discount rate (the member bank remained liable for payment of the loan if the borrower defaulted). An amendment to the Federal Reserve Act in 1916 permitted the Fed to offer "advances," or loans of up to 15 days, to member banks on their own promissory notes, with loans or securities that were eligible for rediscounting serving as collateral. Advances have been the main form of discount window loans since the Great Depression. See Hackley (1973) for a history of the Federal Reserve lending function and Carlson and Duygan-Bump (2016) for information about the mechanics and volumes of Federal Reserve discount window lending and purchases of bankers' acceptances during the 1920 s.

13 The number of designated reserve cities rose over time. For consistency, the information and figures in this article are based on data for 18 cities that were reserve cities throughout the sample period. Similarly, for consistency, we treat St. Louis as a central reserve city throughout the 1920s, even though it was downgraded to reserve city status in 1922.

14 Recall that deposits "due to" banks are deposits that other banks hold with a correspondent bank and are thus liabilities of the correspondent bank. By contrast, deposits "due from" banks are deposits that a given bank holds with correspondents and, thus, are assets of that bank. For consistency in assessing changes in the importance of interbank deposits, we scale deposits due to banks by total assets, even though such deposits are liabilities of the bank in which they are held.

15 Although the relative size of the interbank system fell after the Fed was established, it did not disappear altogether. Watkins (1929) studied how the Fed's establishment affected the demand for interbank balances and concluded that national banks continued to hold some deposits with correspondents for interest income (unlike the Fed, correspondent banks typically paid interest on interbank deposits) and because correspondent banks would invest surplus funds in securities markets on behalf of their respondents.

16 During 1894-1914, the excess reserves/assets ratios of country, reserve city, and central reserve city banks averaged $0.11,0.12$, and 0.08 , respectively. For $1921-28$, the corresponding averages were $0.09,0.08$, and 0.06 .

17 Although central reserve city banks rarely borrowed, during the major banking panics, some of those banks borrowed heavily from their local clearinghouses. See Gorton (1985). The data shown in Figure 15 do not include loans from clearinghouses.

18 National bank reports do not indicate the source of loans. However, Federal Reserve data indicate that loans from the Fed comprised a large share of total borrowing by national banks (and other Fed member banks) during the 1920 s.

19 The Comptroller of the Currency recommended legislation to prohibit banks from having total deposits in excess of 10 times their capital (U.S. Department of the Treasury, 1914, p. 21). However, Congress did not mandate maximum leverage ratios (or, equivalently, minimum capital/assets or capital-to-deposit ratios) until the 1980s (Federal Deposit Insurance Corporation, 2003).

20 The total deposits data underlying Figure 17 include deposits of individuals, firms, financial institutions, and state and local governments, but do not include federal government deposits.

21 One exception might be for country national banks in the South, where the average loans/assets ratio among the eight southern states substantially exceeded the U.S. average in the 1920s. However, the average among the southern states also exceeded the U.S. average during 1910-14 and exhibited considerable intra-year volatility, making it difficult to attribute changes in the loans/assets ratio after 1914 to the presence of the Fed.

$\underline{22}$ Securities issued by the federal government comprised about 8 percent of total national bank assets before 1914 and 10 percent during the 1920s; hence, private securities also comprised larger shares of bank assets in the 1920 s.

$\underline{23}$ Richardson and Troost (2009) show that aggressive lender of last resort action by the Federal Reserve Bank of Atlanta enabled the banks and economy of the southern half of Mississippi to fare better during the crisis than did the banks and economy of the northern half of Mississippi, which was in the district of the less aggressive Federal Reserve Bank of St. Louis. Bordo and Wheelock (2013) attribute the Fed's failure to respond aggressively to the banking panics of the Great Depression to restrictions on Fed lending imposed by the Federal Reserve Act as well as to the Fed's decentralized structure. 


\section{REFERENCES}

Basel Committee on Banking Supervision. Eleventh Progress Report on Adoption of the Basel Regulatory Framework. Bank for International Settlements, October 2016; http://www.bis.org/bcbs/publ/d388.pdf.

Bernstein, Asaf; Hughson, Eric and Weidenmier, Marc D. "Identifying the Effects of a Lender of Last Resort on Financial Markets: Lessons from the Founding of the Fed." Journal of Financial Economics, October 2010, 98(1), pp. 40-53; https://doi.org/10.1016/j.jfineco.2010.04.001.

Bianchi, Javier. "Efficient Bailouts?" American Economic Review, December 2016, 106(12), pp. 3607-59; https://doi.org/10.1257/aer.20121524.

Board of Governors of the Federal Reserve System. Banking and Monetary Statistics, 1914-1941. 1943; https://fraser.stlouisfed.org/title/38, accessed July 12, 2017.

Bordo, Michael D. and Wheelock, David C. "The Promise and Performance of the Federal Reserve as Lender of Last Resort, 1914-1933," in Michael D. Bordo and William Roberds, eds., A Return to Jekyll Island: The Origins, History, and Future of the Federal Reserve. Cambridge and New York: Cambridge University Press, 2013, pp. 59-98; https://doi.org/10.1017/CBO9781139005166.004.

Calomiris, Charles W. and Carlson, Mark A. "Interbank Networks in the National Banking Era: Their Purpose and Their Role in the Panic of 1893." Journal of Financial Economics, September 2017, 125(3), pp. 434-53; https://doi.org/10.1016/j.jfineco.2017.06.007.

Calomiris, Charles W. and Gorton, Gary. "The Origin of Banking Panics: Models, Facts, and Bank Regulation," in R. Glenn Hubbard, ed., Financial Markets and Financial Crises. Chicago: University of Chicago Press, 1991, pp. 109-173.

Carlson, Mark and Duygan-Bump, Burcu. "The Tools and Transmission of Federal Reserve Monetary Policy in the 1920s." Board of Governors of the Federal Reserve System FEDS Notes, November 22, 2016;

https://www.federalreserve.gov/econresdata/notes/feds-notes/2016/tools-and-transmission-of-federal-reserve-monetary-policy-in-the-1920s-20161122.html.

Carlson, Mark; Mitchener, Kris J. and Richardson, Gary. "Arresting Banking Panics: Federal Reserve Liquidity Provision and the Forgotten Panic of 1929." Journal of Political Economy, October 2011, 119(5), pp. 889-924; https://doi.org/10.1086/662961.

Carlson, Mark and Wheelock, David C. "Interbank Markets and Banking Crises: New Evidence on the Establishment and Impact of the Federal Reserve." American Economic Review: Papers \& Proceedings, May 2016a, 106(5), pp. 533-37; https://doi.org/10.1257/aer.p20161044.

Carlson, Mark A. and Wheelock, David C. "Did the Founding of the Federal Reserve Affect the Vulnerability of the Interbank System to Systemic Risk?" Working Paper No. 2016-012B, Federal Reserve Bank of St. Louis, July $2016 \mathrm{~b}$.

Federal Deposit Insurance Corporation. "Basel and the Evolution of Capital Regulation: Moving Forward, Looking Back." January 14, 2003; https://www.fdic.gov/bank/analytical/fyi/2003/011403fyi.html.

Friedman, Milton and Schwartz, Anna J. A Monetary History of the United States, 1867-1960. Princeton: Princeton University Press, 1963.

Gilbert, R. Alton. "Did the Fed's Founding Improve the Efficiency of the U.S. Payments System?" Federal Reserve Bank of St. Louis Review, May/June 1998, 80(3), pp. 121-42;

https://files.stlouisfed.org/files/htdocs/publications/review/98/05/9805ag.pdf.

Gilbert, R. Alton. "The Advent of the Federal Reserve and the Efficiency of the Payments System: The Collection of Checks, 1915-1930." Explorations in Economic History, April 2000, 37(2), pp. 121-48;

https://doi.org/10.1006/exeh.2000.0736.

Gorton, Gary. "Clearinghouses and the Origin of Central Banking in the United States." Journal of Economic History, June 1985, 45(2), pp. 277-83; https://doi.org/10.1017/S0022050700033957.

Hackley, Howard H. Lending Functions of the Federal Reserve Banks: A History. Washington D.C.: Board of Governors of the Federal Reserve System, May 1973. 


\section{Carlson and Wheelock}

Jaremski, Matthew and Wheelock, David C. "Banker Preferences, Interbank Connections, and the Enduring Structure of the Federal Reserve System." Explorations in Economic History, October 2017, 66, pp. 21-43;

https://doi.org/10.1016/j.eeh.2016.08.002.

Kemmerer, Edwin W. Seasonal Variations in the Relative Demand for Money and Capital in the United States. National Monetary Commission. Washington DC: Government Printing Office, 1910.

Miron, Jeffrey A. "Financial Panics, the Seasonality of the Nominal Interest Rate, and the Founding of the Fed." American Economic Review, March 1986, 76(1), pp. 125-40.

Miron, Jeffrey A. and Romer, Christina D. "A New Monthly Index of Industrial Production, 1884-1940." NBER working paper No. 3172, National Bureau of Economic Research, November 1989.

Odell, Kerry A. and Weiman, David F. "Metropolitan Development, Regional Financial Centers, and the Founding of the Fed in the Lower South." Journal of Economic History, March 1998, 58(1), pp. 103-25; https://doi.org/10.1017/S0022050700019902.

Redenius, Scott A. and Weiman, David F. "Banking on the Periphery: The Cotton South, Systemic Seasonality, and the Limits of National Banking Reform," in Paul W. Rhode, Joshua L. Rosenbloom, and David F. Weiman, eds., Economic Evolution and Revolution in Historical Time. Redwood City, CA: Stanford University Press, 2011, pp. 214-42; https://doi.org/10.11126/stanford/9780804771856.003.0009.

Reserve Bank Organization Committee. Report to the Reserve Bank Organization Committee by the Preliminary Committee on Organization. 1914; https://fraser.stlouisfed.org/scribd/?title id=609\&filepath=/files/docs/historical/ federal\%20reserve\%20history/Reserve\%20Bank\%20Organization.pdf.

Richardson, Gary and Troost, William. "Monetary Intervention Mitigated Banking Panics during the Great Depression: Quasi-experimental Evidence from a Federal Reserve District Border, 1929-1933." Journal of Political Economy, December 2009, 117(6), pp. 1031-73; https://doi.org/10.1086/649603.

Sprague, O.M.W. History of Crises under the National Banking System. National Monetary Commission. Senate Document No. 538, 61st Congress, 2d Session. Washington DC: Government Printing Office, 1910.

U.S. Department of the Treasury. Annual Report of the Comptroller of the Currency. Washington DC: Government Printing Office, 1915.

U.S. Office of the Comptroller of the Currency. Annual Report of the Comptroller of the Currency. 1917-1928; https://fraser.stlouisfed.org/title/56, accessed July 12, 2017.

Watkins, Leonard L. Bankers Balances: A Study of the Effects of the Federal Reserve System on Banking Relationships. Chicago: A.W. Shaw Company, 1929.

Weber, Warren E. “Disaggregated Call Reports for U.S. National Banks, 1880-1910." Research Division Digital Archives, Federal Reserve Bank of Minneapolis, 2000; http://research.mpls.frb.fed.us/research/economists/wewproj.html.

Wheelock, David C. "Seasonal Accommodation and the Financial Crises of the Great Depression: Did the Fed 'Furnish an Elastic Currency?'" Federal Reserve Bank of St. Louis Review, November/December 1992, 74(6), pp. 3-18; https://files.stlouisfed.org/files/htdocs/publications/review/92/11/Seasonal Nov Dec1992.pdf.

Wheelock, David C. "Economics and Politics in Selecting Federal Reserve Cities: Why Missouri Has Two Reserve Banks." Federal Reserve Bank of St. Louis Review, Fourth Quarter 2015, 97(4), pp. 269-88; https://doi.org/10.20955/r.2015.269-88.

White, Eugene N. The Regulation and Reform of the American Banking System, 1900-1929. Princeton: Princeton University Press, 1983; https://doi.org/10.1515/9781400857449.

Yellen, Janet L. "Supervision and Regulation." Testimony before the Committee on Financial Services, U.S. House of Representatives, Washington DC, September 28, 2016; https://www.federalreserve.gov/newsevents/testimony/yellen20160928a.htm. 